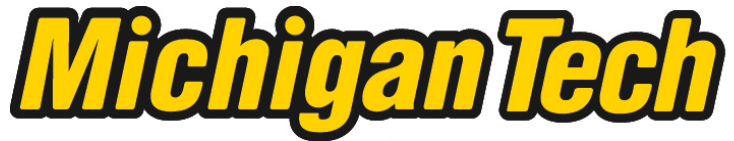 \\ Michigan Technological University Create the Future Digital Commons @ Michigan Tech
}

Dissertations, Master's Theses and Master's Reports - Open

Dissertations, Master's Theses and Master's

Reports

2014

Do increases in oil prices precede U.S. recessions?

Thanyalak Suthijindawong

Michigan Technological University

Follow this and additional works at: https://digitalcommons.mtu.edu/etds

Part of the Economics Commons

Copyright 2014 Thanyalak Suthijindawong

\section{Recommended Citation}

Suthijindawong, Thanyalak, "Do increases in oil prices precede U.S. recessions?", Master's Thesis, Michigan Technological University, 2014.

https://doi.org/10.37099/mtu.dc.etds/740

Follow this and additional works at: https://digitalcommons.mtu.edu/etds

Part of the Economics Commons 


\title{
DO INCREASES IN OIL PRICES PRECEDE U.S. RECESSION?
}

By

Thanyalak Suthijindawong

\begin{abstract}
A THESIS
Submitted in partial fulfillment of the requirements for the degree of MASTER OF SCIENCE In Applied Natural Resource Economics

MICHIGAN TECHNOLOGICAL UNIVERSITY

2014
\end{abstract}

Copyright 2014 Thanyalak Suthijindawong 
This thesis, "Do increases in oil prices precede U.S. recessions?" is hereby approved in partial fulfillment of the requirement for the Degree of MASTER OF SCIENCE IN APPLIED NATURAL RESOURCE ECONOMICS.

\author{
School of Business and Economics
}

Signatures:

Thesis Advisor

Mark C. Roberts

Committee Member

Gary A. Campbell

Committee Member

Roger M. Turpening

School Dean

Eugene R. Klippel 


\section{Table of Contents}

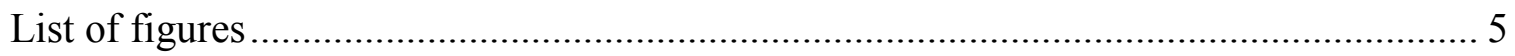

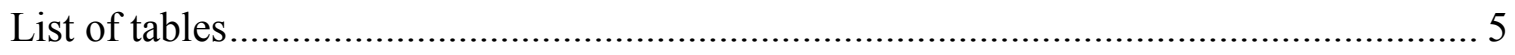

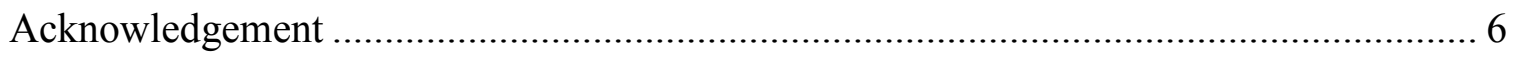

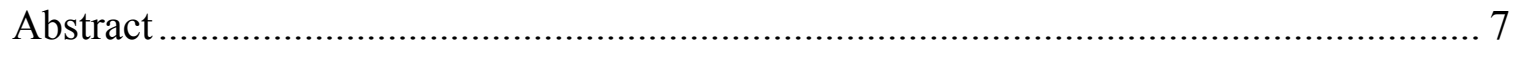

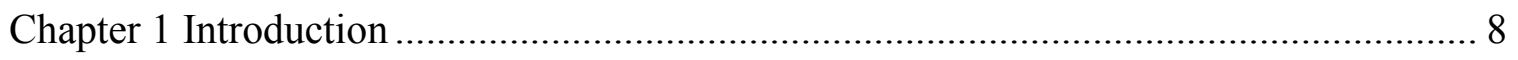

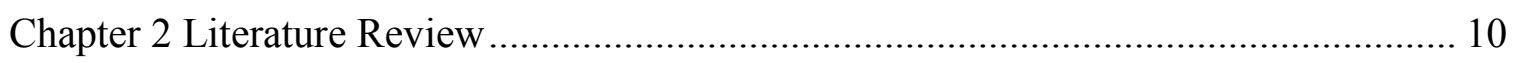

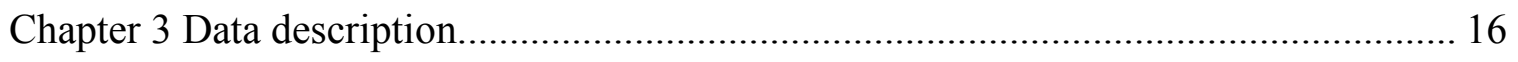

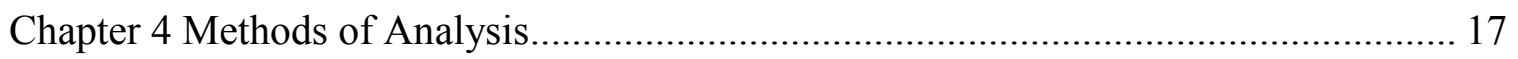

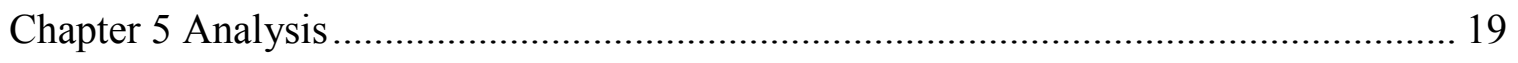

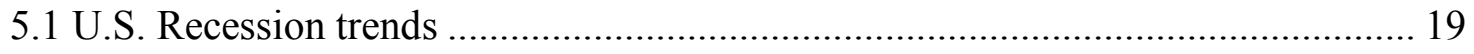

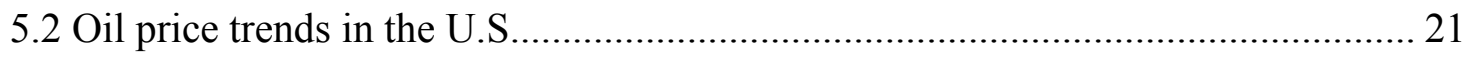

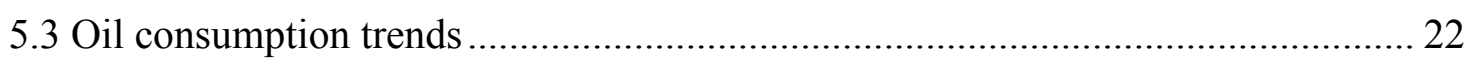

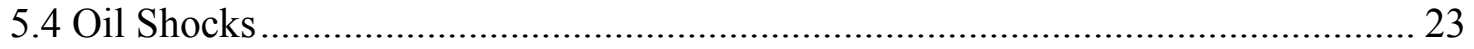

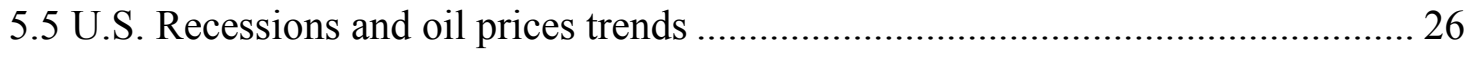

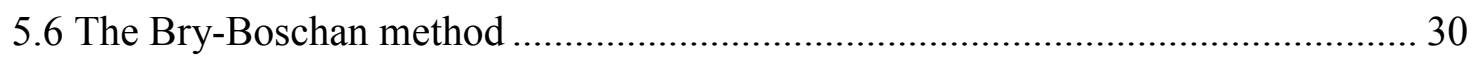

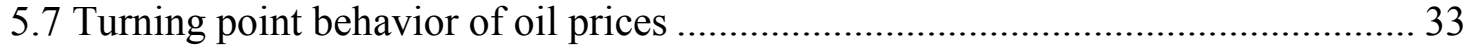

5.8 Correlation between real U.S. GDP and real oil prices ................................... 36

5.9 Correlation between WPU oil price index cycles and NBER U.S. cycle .............. 36

5.10 Reproduction of the Hamilton model ......................................................... 37

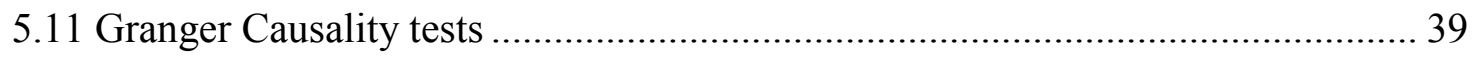

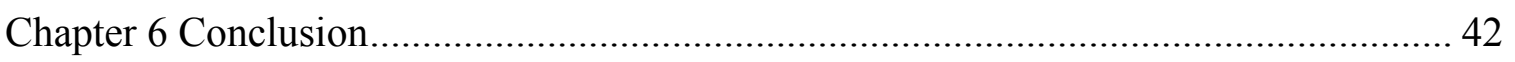

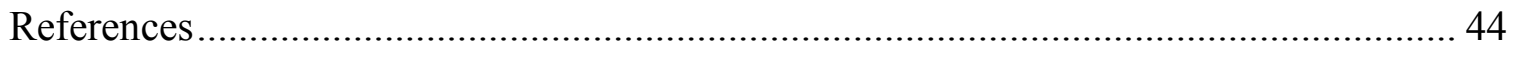

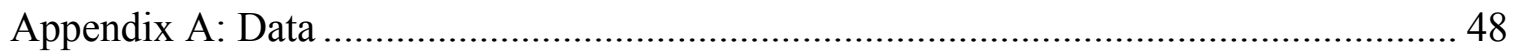




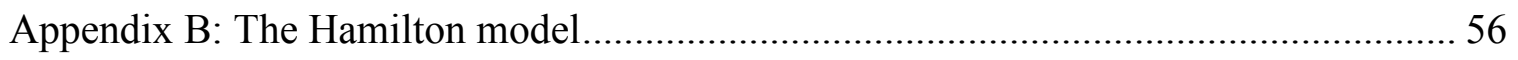

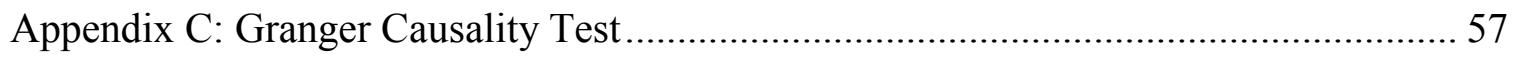

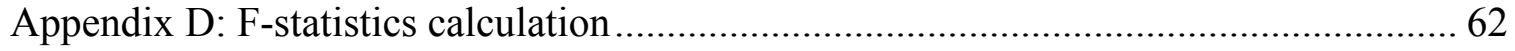

Appendix E: Overview of the studies cited and their principal results........................... 64 


\section{List of figures}

Figure 1: GDP in billions of chained 2005 dollars and U.S. recessions ......................... 20

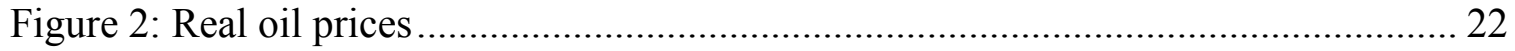

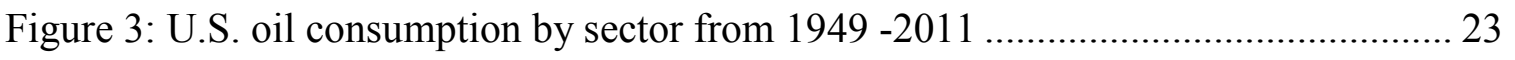

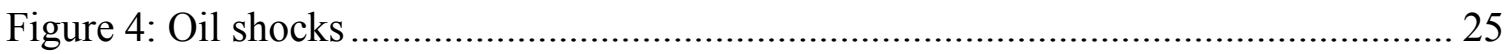

Figure 5 : Percentage change in producer prices index for oil price and U. S. Recessions

Figure 6: Producer price index for oil prices, U.S. recessions, and oil shocks................ 29

Figure 7: Producer price index for oil price, U.S. recessions from NBER, and oil price

cycles. 34

\section{List of tables}

Table 1: Economic indicators during post- War recessions......................................... 21

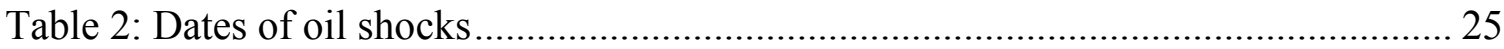

Table 3: Turning points in oil price identified using the Bry- Boschan method .............. 32

Table 4: Turning points in GDP identified using the Bry- Boschan method................... 32

Table 5: The result of turning point comparison by using the Bry - Boschan method to identity GDP and compared with the oil prices peaks ............................................. 35

Table 6: The result of turning point comparison by Bry - Boschan method (GDP troughs)

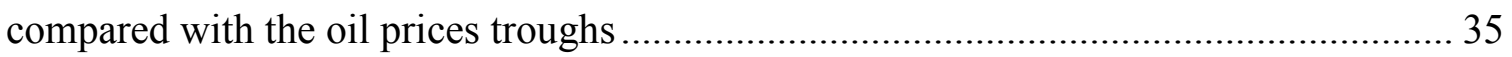

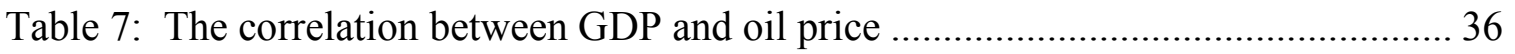

Table 8: Correlation between the WPU oil price index cycles and NBER US cycles ..... 37

Table 9: Granger Causality F-statistics (5\% percent level of significance)..................... 41

Table 10: Statistical summary output result for the Hamilton model ............................... 56

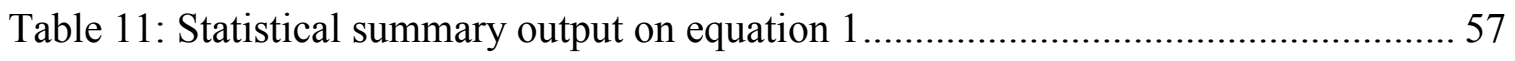

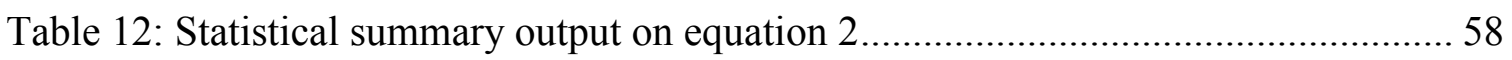

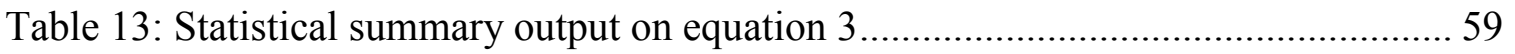

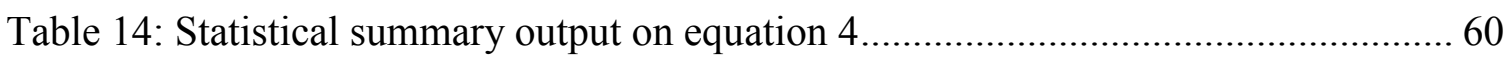

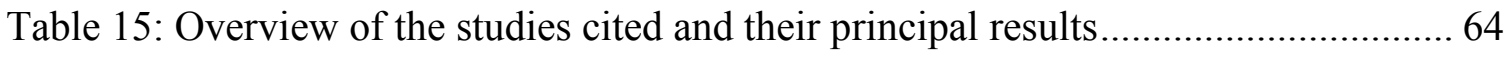




\section{Acknowledgement}

First of all, I would like to show my gratitude to Michigan Technological University especially athletes who financially supported my U.S. education.

Next, my advisor, Dr. Mark C Roberts, without his mentoring, guidance and support, I would not be able to finish my degree.

Michigan Tech teachers provided the knowledge that aided me in my research.

My friends at Michigan Tech helped me not only through my school difficulties but also through life outside of school.

My family comes last but they are really important. Without my family, I would not have a chance to grow up. They gave me superb support and raised me as best as parents possibly could.

If there were any words better than "thank you very much", I would say them.

Thank you very much. 


\begin{abstract}
This thesis examines the relationship between oil prices and economic activity, and it attempts to address the question: do increases in oil prices (oil shocks) precede U.S. recessions? This paper also applied macroeconomics, either through the direct use of a macroeconomic point of view or using a combination of mathematical and statistical models. Two mathematical and statistical models are used to determine the ability of oil prices to predict recessions in the United States. First, using the binary cyclical (Bry-Boschan method) indicator procedure to test the turning point of oil prices compared with turning points in GDP finds that oil prices almost always turn five month before a recession, suggesting that an oil shock might occur before a recession. Second, the Granger causality test shows that oil prices change do Granger cause U.S. recessions, indicating that oil prices are a useful signal to indicate a U.S. recession. Finally, combining this analysis with the literature, there are several potential explanations that the spike in oil prices result in slower GDP growth and are a contributing factor to U.S. recessions.
\end{abstract}




\section{Chapter 1 Introduction}

The effect of an unfavorable oil shock on aggregate output has been the focus of economic research for a long time. Oil is one of the important inputs to an economy; changing or increasing oil prices has a large impact on an economy as a whole. Hamilton (1983) presented strong evidence indicating that an increase in oil prices has been one of the primary causes of recessions, which is a period in which economic activity declines for two or more consecutive quarters. Over the past few decades, ten out of eleven U.S. recessions were preceded by an increase in oil prices (oil shocks). The exception is the recession of 1960, as shown later in Figure 4.

Many economists continue to research oil price shocks including Kilian (2008c), Jones et al (2004), Brow and Yucel (2002), Mork and Hall (1980), and Rasche and Tatom (1977). The literature concludes that significant increases in oil prices (oil shocks) lead to slower GDP growth and was a contributing factor of U.S. recessions, higher unemployment, and increases in the cost of living. Since 1947, the United States has experienced eleven recessions, causing a drop in stock market prices, decreases in housing prices and high unemployment. Furthermore, there is some evidence that the effect of oil prices on the macroeconomy may not be linear; a negative effect of a sharp increase in oil prices is more outstanding than the positive effect of the same size of a decrease in oil prices.

This paper tests for a relationship between oil prices and economic activity, and it attempts to address the question: are increases in oil prices precede U.S. recessions? Since oil is an important input into the economy, an increase in oil prices will put great pressure on other prices. Moreover, a number of studies have tested and concluded that changes in oil prices and economic output may not just be a statistical coincidence and that these two events occur in the same time 
period. 1 However, Lardic and Mignon (2006), Blanchard and Gali (2007), Segal (2007), and Katayama (2012) consider the oil price shock effect a less important source of macroeconomic fluctuations and speculate that the effect of oil shocks has decreased during the post-World War II period.

There are no studies that specifically focus on the oil shock effect in the most recent U.S. recession. What makes this paper different from previous studies is that it uses the Bry-Boschan method to examine the relationship between oil prices and U.S. recessions and finds that oil price shocks precede recessions. A series of contributions by Hamilton (1983, 1996, 2005, and 2009) has presented strong evidence that one of the main reasons for the recessions in the United States is due to an increase in oil prices.

This paper is organized as follows: Section 2 reviews the previous studies on the relationship between the oil prices and U.S. recessions. Section 3 describes the data being used. Section 4 describes the methods used. Section 5 analyzes all the data using the various methods to describe the relationship between oil prices and U.S. recessions. Section 6 contains a conclusion of this paper's findings.

\footnotetext{
1 Hamilton (1983), Burbidge and Harrison (1984), Gisser and Goodwin (1986), Daniel (1997), Carruth, Hooker, and Oswald (1998), and Hamilton (2003) etc.
} 


\section{Chapter 2 Literature Review}

Energy, specifically oil, is one of the most important and crucial raw materials in the United States' economy. Oil products are generally used for different purposes such as transportation and heating. One of the largest consumers of petroleum in the United States is the transportation sector, including the transportation necessary for the supply and use of petroleum. Thus, the price of oil is one of the most important prices in the economy. The price of oil is widely used to indicate the value of other energy resources. For this reason many studies have been conducted to better understand the relationship between oil prices and macroeconomics, either through the direct use of a macroeconomic point of view or using a combination of mathematical and statistical models. ${ }^{2}$ Many previous studies have concluded that oil prices have been a significant influence on U.S. economic activity. Therefore, significant increases in oil prices could be a contributing factor to U.S. recessions.

According to Hamilton (1996), an oil shock occurs when oil prices exceed its three years peak. Also, Hamilton (2003) identifies an oil shock to be equal to the difference between the current oil price and the maximum price in the past four or twelve quarters if the difference is positive and is equal to zero otherwise. Hamilton (1983 and 1985) describes the primary catalysts for oil price spikes to

\footnotetext{
2 The literature on the relationship between a spike up in oil price and macroeconomic activity can be divided into two broad strands:
}

1. Examination of the direct affects of oil price increases on aggregate output such as Hamilton (1983, 1985, 1988, 1996, 2003, and 2005), Kilian (2005), Rogoff (2006), Rotemberg and Woodford (1996).

2. Examination of the direct and indirect effects arising from the central bank policy responses to the inflation caused by increasing oil prices such as Bohi (1989), Bernanke et al (1997), Hamilton and Herrera (2004). 
include political disturbances such as the Suez Crisis, the Arab-Israel War, the Iranian Revolution, the Iran and Iraq War, and the Persian Gulf War. Moreover, oil shocks have, in the past, largely been the result of conflicts on the supply side. However, there was an exception with an oil shock that took place from 2007 to 2008. This oil shock occurred due to rapidly increasing energy consumption in both India and China, which has been growing at a $7 \%$ compounded annual rate over the last two decades (Hamilton 2009).

The macroeconomics of oil price shocks has had a long history that began with the first oil crises in 1973. Hamilton (1983) believes that all but one of the U.S. recessions since World War II has been preceded by an increase in the price of oil, except the recession of $1960 .{ }^{3}$ He also claims that the relationship between oil prices and the U.S. economy are systematic, in which oil price increases are followed by a decline in output, which causes a recession, three to four quarters later. ${ }^{4}$ Rotemberg and Woodford (1996) also show the results from a simulation in which a $10 \%$ increase in energy prices could lead to a $2.5 \%$ drop in output six quarters later.

However, the effect of oil shocks can also be asymmetric and can either increase or decrease the macroeconomy because the insecurity of oil prices can cause delays in business investments. ${ }^{5}$ Increases also encourage resource reallocation. ${ }^{6}$ When oil prices decline, they encourage the transfer of aggregate

\footnotetext{
${ }^{3}$ Brown and Yucel (2002) indicate that increases in oil prices proceeded eight out of nine post WWII recessions in the U.S.

${ }^{4}$ Rachel and Tatom (1997), Baily (1981), Jones, Leidy, and Paik (2004), and Wei (2003) also believe that oil shocks affect macroeconomic activity.

5 Bernanke ( 1983), Pindyck (1991), Hamiltion (1996), Lee et al (1995), a Mork ( 1989), Davis and Haaltiwanger (1998), and Ferderer (1996)

${ }^{6}$ Lilien (1982), Hamilton (1988), Jones, Leiby, and Paik (2003), Loungani (1986)
} 
channels (output, income, and wage) and allocate channels (labor and capital) to respond to the economic effects. Furthermore, there is some evidence that the effect of oil prices on the macroeconomy may not be linear; a negative effect of a spike up in oil prices is more outstanding than the positive effect of the same size of a decrease in oil prices.

There are many studies on the effect of oil price shocks. ${ }^{7}$ There are six transmission channels that affect the following variables when there are changes in oil prices, according to Brown and Yucel (2002). The first is a supply-side effect, which focuses on the direct impact on output due to the change in marginal production cost caused by oil price shock. ${ }^{8}$ Also, the supply - side effect causes a reduction in the accessibility of basic inputs to production, shifts in demand, monetary policy changes and adjustment costs. Second, the wealth transfer effect emphasizes the different marginal consumption rates of petrodollar and that of ordinary trade surpluses. The result of this effect is a shift in purchasing power from the oil import nations to oil export nations which reduces consumer demands in oil import nation and increase consumer demand in oil export nations. Third is the inflation effect, which looks at the relationship between domestic inflation and oil prices. An increase of the oil price increases the inflation rate, which will raise the cost of living. Fourth is the real balance effect which includes the change in money demand and monetary policy. If monetary policy fails to meet the growth of money demand, this would boost the interest rate, and slow economic growth. Fifth is sector adjustment, which is the adjustment cost of

\footnotetext{
7 Mork (1989), Lardic and Mignon (2006), Hooker (1996), and Blanchard and Gali (2010) find that the relationship between the oil price and macroeconomy is weakening. Davis and Haltiwanger (2001) also find evidence that the impact of oil price shocks on manufacturing employment growth is weaker in an extended sample including the late 1980 s and the early 1990 s.
}

${ }^{8}$ See Rasche and Tatom (1977 and 1981), Barro (1984), and Brown and Yucel (1999) 
changing the industrial structure, and is mainly used to explain the asymmetric impact of oil price shocks. Asymmetry in oil prices shocks is that a negative effect of a spike up in oil prices is more outstanding than the positive effect of the same size of a decrease in oil prices. Finally, the unexpected effect focuses on the uncertainly of oil prices and its impact on economic activity. It can cause insecurity and delays in business investments and encourage resource reallocation. Bernanke et al. (1997) concluded that about two-thirds of the quarters with decreases in output after an oil shock can be attributed to monetary policy tightening, specifically when the increase in oil prices is followed by rise in the federal fund rate.

Nordhus (2007) finds that oil prices can directly affect output through an increase in inflation and tight monetary policy as a response of the central bank. This will cause output to drop and can affect the consumer by increasing consumption taxes. Bernanke (1983) claims that oil shocks may disrupt the purchase of more expensive consumer and investment goods, which may impact the economy in the short-run. A major oil price shock can cause people to be uncertain about the future and reduce spending on items such as cars, housing, appliances, and investments.

However, there are several pieces of research that indicate that the macroeconomic effect of oil price shocks have decreased since 1970. Blanchard and Gali (2007) find that there are at least four reasons for the decreased affect on inflation and macroeconomic activity such including prices, wages, output, and employment, following the recent spike in oil prices. In the general market, the first reason is due to more choice of the alternate energy causing the lack of effect on the oil prices and decline in volatility. Secondly, the lack of resources has caused a smaller share of oil production which cause the production to be controlled by a small group of people allowing them to dictate the market based 
on their group of strategy. The third reason is the increase of resources that have been reallocated, which created more flexibility in labor market. Finally, the improvement in monetary policies helped to improve the economy as a whole. However, Segal (2007) presents several arguments as to why high oil prices in the past several years have not slowed the economy. He says that the importance of oil prices is often overemphasized. In addition, high oil prices have not led to monetary tightening in the past few years as they are no longer considered when calculating core inflation. Moreover, Katayama (2012) also mentions three reasons that have reduced the effects of oil price shocks. They include high competition in transportation, an increase in energy efficiency, and oil prices have less effect on the people lives because currently, people have the option of alternative energy to choose from.

However, Barsky and Kilian (2002) argue that recessions may be partly exogenous due to the change in monetary policy, which occurred at the same time as the oil prices shock. Bernanke, Gertler, and Watson (1997) argue that U.S. recessions happened due to the rise in interest rates, resulting from the Federal Reserve's endogenous response to higher inflation, which was a result of the oil shock.

There is further discussion on the impact that oil shocks have had on the United States economy. Hamilton (2009) concludes that oil shocks have historically contributed to past U.S. recessions and he also claims that if there had been no oil shock, in 2007-2008 the U.S. economy would have grown slowly, but it would not have fallen into a recession. Thus, Blanchard-Gali support Hamilton in that the oil shock in the 2007-2008 periods led to the recession in 2009. Gisser and Goodwin (1986) found that oil prices have had further impacts on the macroeconomic indicators, exceeding the effect of monetary and fiscal policy. 
Several studies have tested and concluded that co-movement of oil price and economic output may not be just a statistical coincidence. The scholars who support this hypothesis include Rasche and Tatom (1977, 1981), Burbidge and Harrison (1984), Santini (1985, 1994), Gisser and Goodwin (1986), Rotemberg and Woodford (1996), Daniel (1997), Raymond and Rich (1997), Carruth, Hooker, and Oswald (1998).

Finally, according to the National Bureau of Economic Research (NBER), the recent U.S. economy was in the longest and worst recession since World War II, and was 18 months from December 2007 to June 2009. Hamilton (2009) and Kilian (2009) note that at the beginning of July 2008 the oil price reached 145 dollars per barrel, which is the highest price in history and they claim it significantly contributed to the recession in 2009. Carstensen, Elstner, and Paula (2011) also claim that the increase in oil price in 2007 to 2008 caused a 0.8 percent reduction of German GDP in 2009 and contributed to the recession in 2009. Moreover, Hamilton (2009) said "the evidence to me is persuasive that, if there had there been no oil shock, we would have described the U.S. economy from 2007 to 2008 as growing slowly, but not in a recession". He also claims that the collapse in automobile purchases, deteriorating consumer sentiment, and slowdown in overall consumption spending, was caused by the oil shock and was one of the contributing factors causing the recent U.S. recession in 2009. Appendix E also summarizes the studies that related to the research topic. 


\section{Chapter 3 Data description}

This research analyses the relationships between oil prices and U.S. economic activity using United States data. The sample period of the analysis and model is from January 1949 to December 2012 on a quarterly basis. This data includes the first post-World War II period, the recession in 1949, which is the earliest data that the National Bureau of Economic Research (NBER) has in the record of U.S. Business Cycle expansions and contractions. This study uses real gross domestic product (real GDP) and real oil prices from the U.S. Department of Commerce Bureau of Economic Analysis. Also, it uses the quarterly growth in real GDP from the website Economagic. Oil price is measured by the producer price index for oil prices (WPU 0561 Oil Price Index) using monthly data from the U.S. Bureau of Labor Statistics. This paper converts the monthly data to quarterly data by averaging every three months of data into a single quarterly period. Further, this study also uses business cycle expansions and contractions identified by the National Bureau of Economic Research (NBER). This is the standard or "official" designation of U.S. business cycles. 


\section{Chapter 4 Methods of Analysis}

This study uses a dynamic time series-based regression of the historical data to evaluate the hypothesis of Hamilton (2005). This is done using the same set of data as used by Hamilton. Regressions are one of the most popular and wide spread methods used to analyze the relationship between oil prices and U.S. economic activity. ${ }^{9}$ The regression was run using a lagged change in quarterly GDP growth rate and a lagged logarithmic change in quarterly nominal oil price (WPU 0561 Oil Price Index) from 1949II to 2005II. The specific data used can be found in appendix A and the result of this regression can be found in appendix B. These regression results will be used in an attempt to duplicate the results from Hamilton in order to predict the relationship between oil prices and U.S. recessions.

Moreover, the regression method will be used to examine and predict the relationships between the oil prices and U.S. recessions in the Granger Causality tests. The eight periods of lagged changes in quarterly GDP growth rate and the eight period of lagged logarithmic change in nominal oil price but from 1949 II to 2012 II also are used. The result of this Granger Causality test can be found in appendix C.

The Bry- Boschan method is used to identify the turning points in oil price and GDP cycle, which no other research papers have used to predict the relationship between oil prices and U.S. recessions. This paper tries to find a consistent relationship over time with movements and changes in oil prices and U.S. recessions by using the Bry- Boschan method to identify the turning point of

\footnotetext{
${ }^{9}$ Hamilton (1983), Hamilton (2003), Hamilton (2005), Hooker (1996) ,and Mork (1989)
} 
these cycles. After the turning points are found, they will be used to compare the GDP peaks and troughs with those of oil prices

Correlation tests are used to examine the oil prices cycle and GDP cycle, to find the correlations between these. This correlation tests the relationship between the WPU oil price index cycles from the Bry - Boschan procedure and the NBER U.S. cycle. Also, this paper uses the correlation test with the oil prices and U.S. GDP to examine how they are correlating over time. 


\section{Chapter 5 Analysis}

\subsection{U.S. Recession trends}

A recession is a period in which economic activity declines in two or more consecutive quarters. In the United States, most organizations such as universities, academics, economics, policy makers, and businesses use the recessions identified by the Business Cycle Dating Committee of the National Bureau of Economic Research. The National Bureau of Economic Research (NBER) defines an economic recession as: "a significant decline in economic activity spread across the economy, lasting more than a few months, normally visible in real GDP, real income, employment, industrial production, and wholesale-sales". There are many different factors of economic activity that work together to contribute to recessions. These include investment, government spending, net export activity, and consumption. Moreover, these factors are driven by other things such as corporate investment decisions, interest rates, demographics, employment levels and skills, household savings rates, and government policies. Over the past decades since 1947, the United States has experienced eleven recessions which caused a drop in stock market prices, decreases in housing prices, high unemployment, low economic growth or high inflation. A recession can last from eight months through twenty-four months. Figure 1 shows the U.S. GDP and the recessions as bars, in which GDP is one factor that can indicate a recession. No single indicator can predict or indicate a recession. It depends on many different factors, including GDP, employment, investment spending, capacity utilization, and household income, and others. 


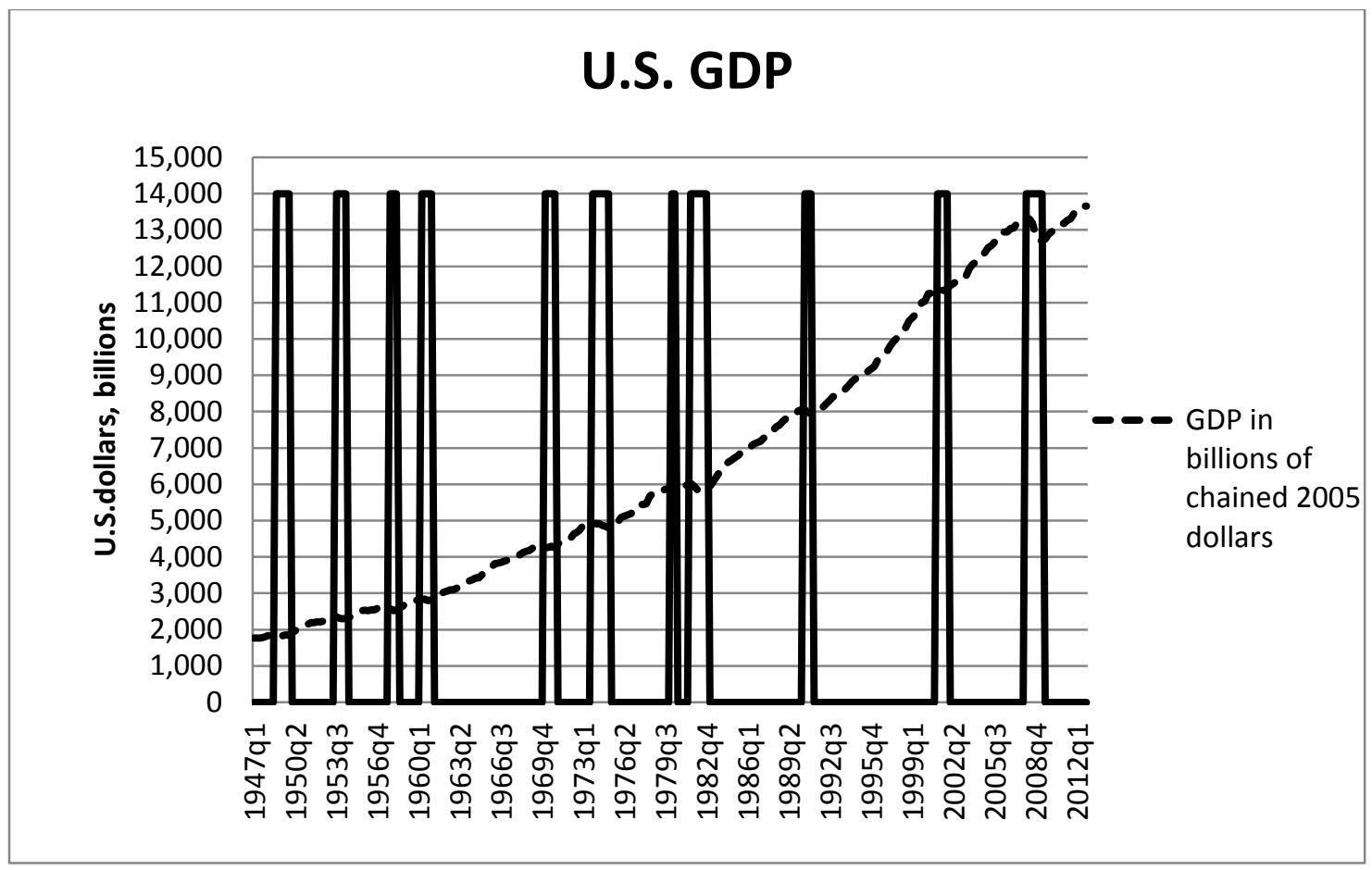

Figure 1: GDP in billions of chained 2005 dollars and U.S. recessions

Note: Recessions identified by the National Bureau of Economic Research (NBER) and U.S. GDP from Economagic.

The recent U.S. recession was the longest and most profound recession since World War II and was 18 months from December 2007 to June 2009, which is shown in Table 1. Table 1 also shows all eleven U.S. recessions since World War II compared with the percentage change in GDP, consumption, and investment. The collapse in GDP and investment in the 2009 U.S. recession was the most intense of the post- war period. However, the cumulative percent change in consumer consumption was not the deepest of the post-war period 
Table 1: Economic indicators during post- War recessions

\begin{tabular}{|l|c|c|c|c|}
\hline \multicolumn{1}{|c|}{ Dates } & \multicolumn{3}{|c|}{ Cumulative Percent Change } \\
\hline Nuration & GDP & Consumption & Investment \\
\hline (months) & 11 & $-1.60 \%$ & $3.40 \%$ & $-10.20 \%$ \\
\hline July 1953 - May 1954 & 10 & -2.6 & -0.5 & -3.4 \\
\hline Aug. 1957 - April 1958 & 8 & -3.7 & -1.3 & -8 \\
\hline April 1960 - Feb. 1961 & 10 & -1.6 & 1 & -5.1 \\
\hline Dec. 1969 - Nov. 1970 & 11 & -0.6 & 2.5 & -2.6 \\
\hline Nov. 1973 - March 1975 & 16 & -2.8 & -0.7 & -18.4 \\
\hline Jan. 1980 - July 1980 & 6 & -2.2 & -1.2 & -8.1 \\
\hline July 1981 - Nov. 1982 & 16 & -2.7 & 0.1 & -9.3 \\
\hline July 1990 - Mar. 1991 & 8 & -1.4 & -0.7 & -7.2 \\
\hline March 2001 - Nov. 2001 & 8 & -0.3 & 1.2 & -3.2 \\
\hline Dec. 2007 - June 2009 & 18 & -4.1 & -2.3 & -23.4 \\
\hline
\end{tabular}

Note: Data comes from National Bureau of Economic Research based on data from the Bureau of Labor Statistics, and the Bureau of Economic Analysis.

\subsection{Oil price trends in the U.S}

Oil prices, like other commodity prices, experience wide swings in times of shortage or oversupply, as shown in the Figure 2. Correspondingly, oil prices are sensitive, hard to predict, and have many short-term fluctuations based on demand and supply, such as the increase in the oil prices as a result of the Middle East supply interruption during the Yom Kippur War and the later crises in Iran and Iraq. Before OPEC was established in 1960, the price of oil was low, ranging between $\$ 2.50$ to $\$ 3$ per barrel. Prior to OPEC, the Texas Railroad Commission, attempted to control oil prices through limitations on production. OPEC replaced the Texas Railroad Commission in the 1970's by monitoring the production capacity and attempting to limit production. Nowadays OPEC is the only organization that tries to control oil prices, since OPEC is the major oil supplier throughout the world. The price will fluctuate according to supply and demand in 
the market with OPEC attempting to keep prices in a certain range. The volatile history of OPEC has varied between restricting supply to increase prices and trying to prevent them from falling. Currently, the leadership of Saudi Arabia involves a deliberate strategy to stabilize prices by adjusting production. Their strategy has not had the ability to smooth out price changes, as shown by the large changes after 2005. The long run demand responses to increases in oil prices were more important than the short run responses.

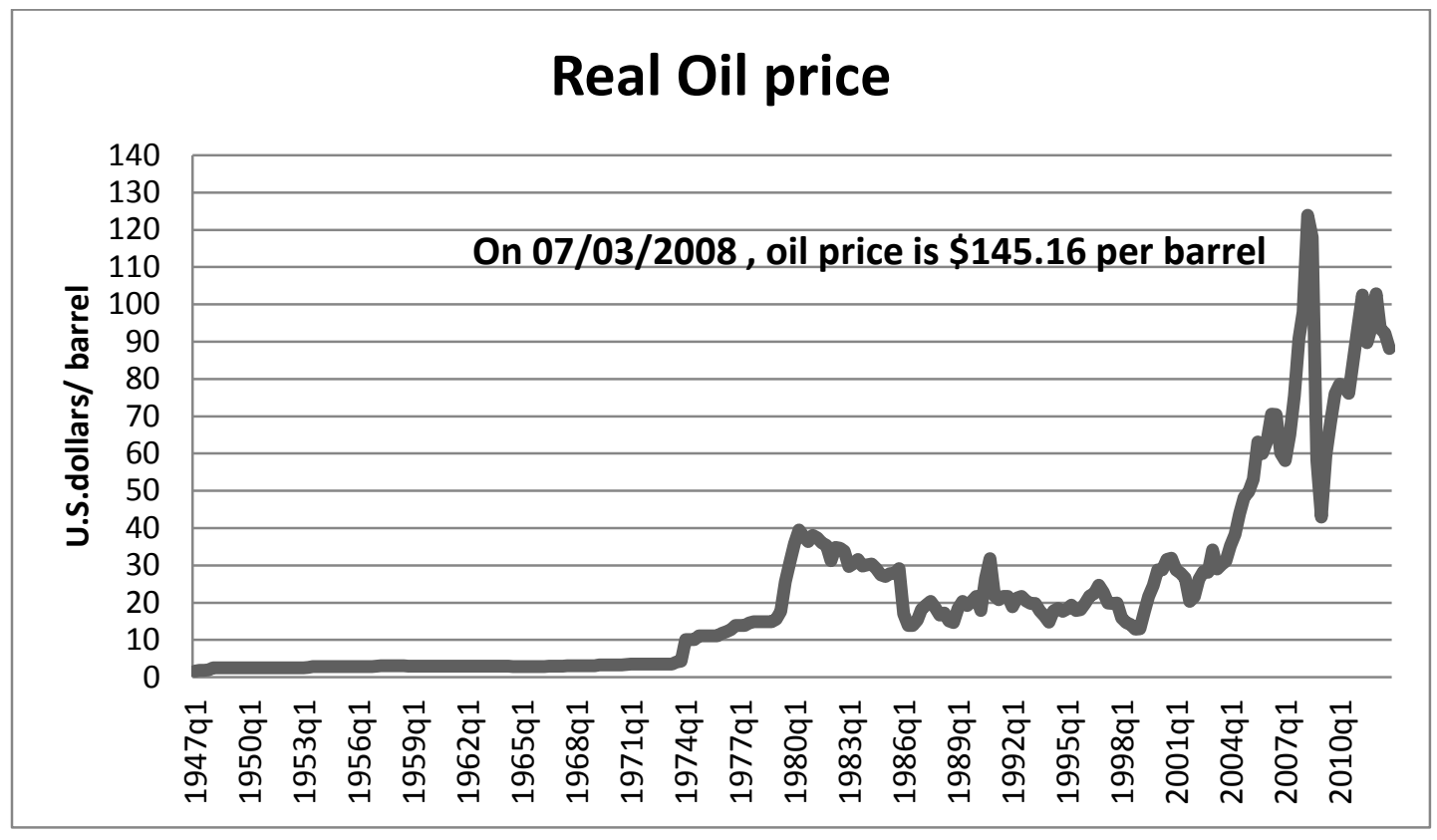

Figure 2: Real oil prices

Note: Oil prices from the U.S. Department of Commerce Bureau of Economic Analysis

\subsection{Oil consumption trends}

Oil is one of the most important, fundamental and crucial raw materials in the United State economy. Oil products are used for many different purposes, such as transportation, which is the largest consumer of petroleum in the United States. Figure 3 shows petroleum consumption in the United States from 1949 to 2011 
(obtained from the Information Administration (EIA)). The total petroleum consumption in the U.S. has been increasing in the past few decades, except for the significant decrease in the late 1970s and the early 1980s. In 1970, U.S. petroleum production reached its peak; after that, any increase in petroleum consumption has been met largely by imports from other countries because the United States cannot produce enough petroleum to supply increases in the demand for oil. The transportation sector consumes more than half of U.S. petroleum.

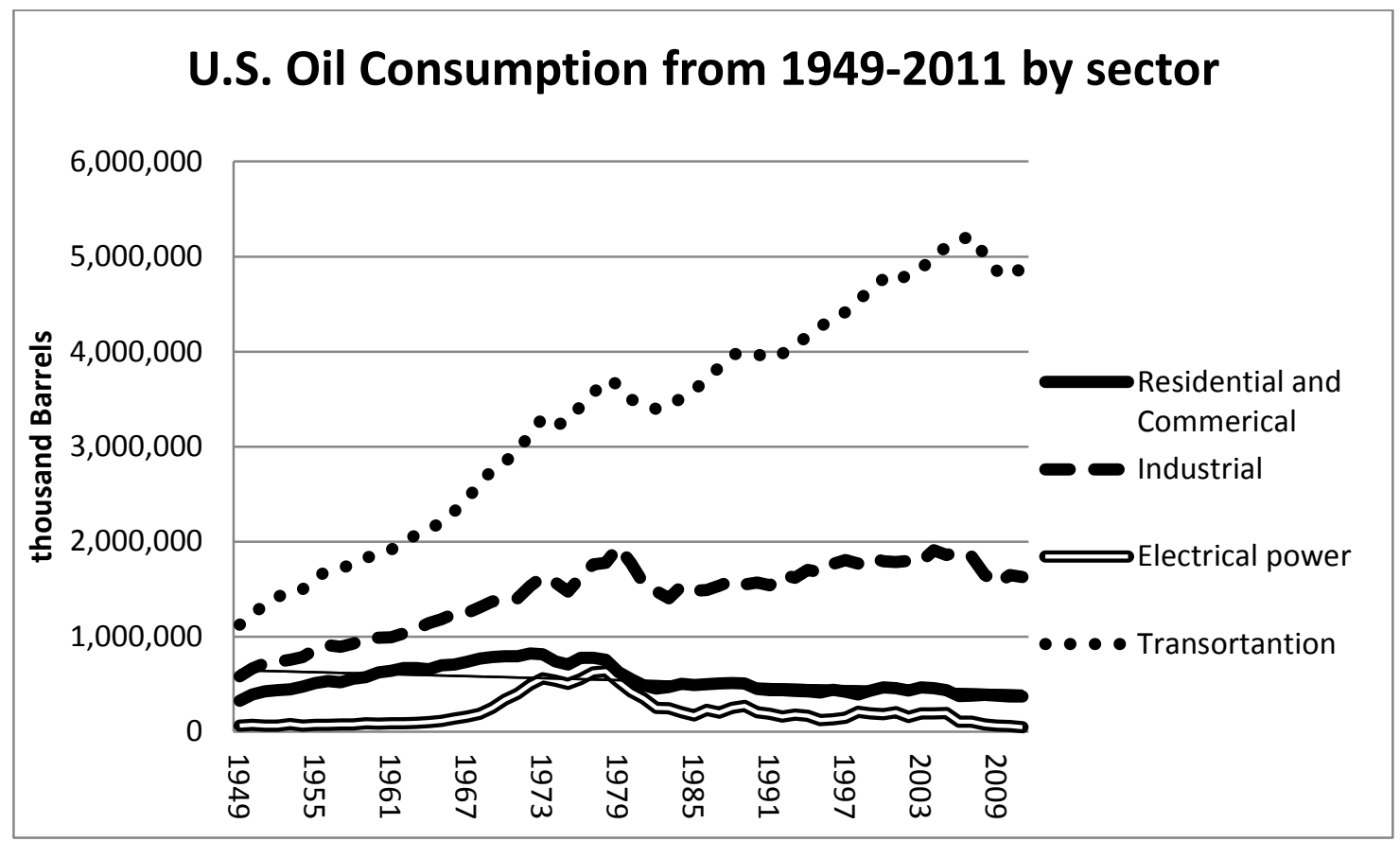

Figure 3: U.S. oil consumption by sector from 1949 -2011

Note: U.S. oil consumption by sector from U.S. Energy Information Administration (EIA)

\subsection{Oil Shocks}

An oil shock is a large positive increase in oil prices. According to Hamilton (2003), an oil shock occurs when oil price exceeds the three years peak shown in Figure 4. Table 2 also shows the date whenever oil shock occurs. Oil 
shocks are calculated using the previous three years compared with oil prices at that time. If the oil prices are lower when compared with previous three years, this indicates no oil shock has happened. However, if oil prices were higher than any price in the previous three years, an oil shock would take place. Oil shocks can happen from demand increases which contribute significantly to the volatility in price. A supply shock (oil production and reserve shock) can also create an oil price shock, which affects current and future oil production. Moreover, oil shocks affect the economy through consumer spending on other goods; as well as a firm's spending for new investment projects. Oil price increases raise the input cost of production and thus reduce production. Oil shocks also have an effect on the rate of inflation. Greenspan (2004) determined that the results of oil price shocks have a negative effect on economic activity and employment by causing a firm to face higher costs of production and a rise in the inflation rate. Figure 6 compares oil prices, oil shocks and recessions to identify the oil shocks from 1947 to 2012 on a quarterly basis. However, several oil shocks have occurred without causing a recession but most of them do. Moreover, ten out of eleven U.S. recessions have been preceded by an oil shock, with the exception of the recession in 1960 which was not associated with an oil shock. This fact has led to a general acceptance that oil price shocks are a likely cause of recessions. 


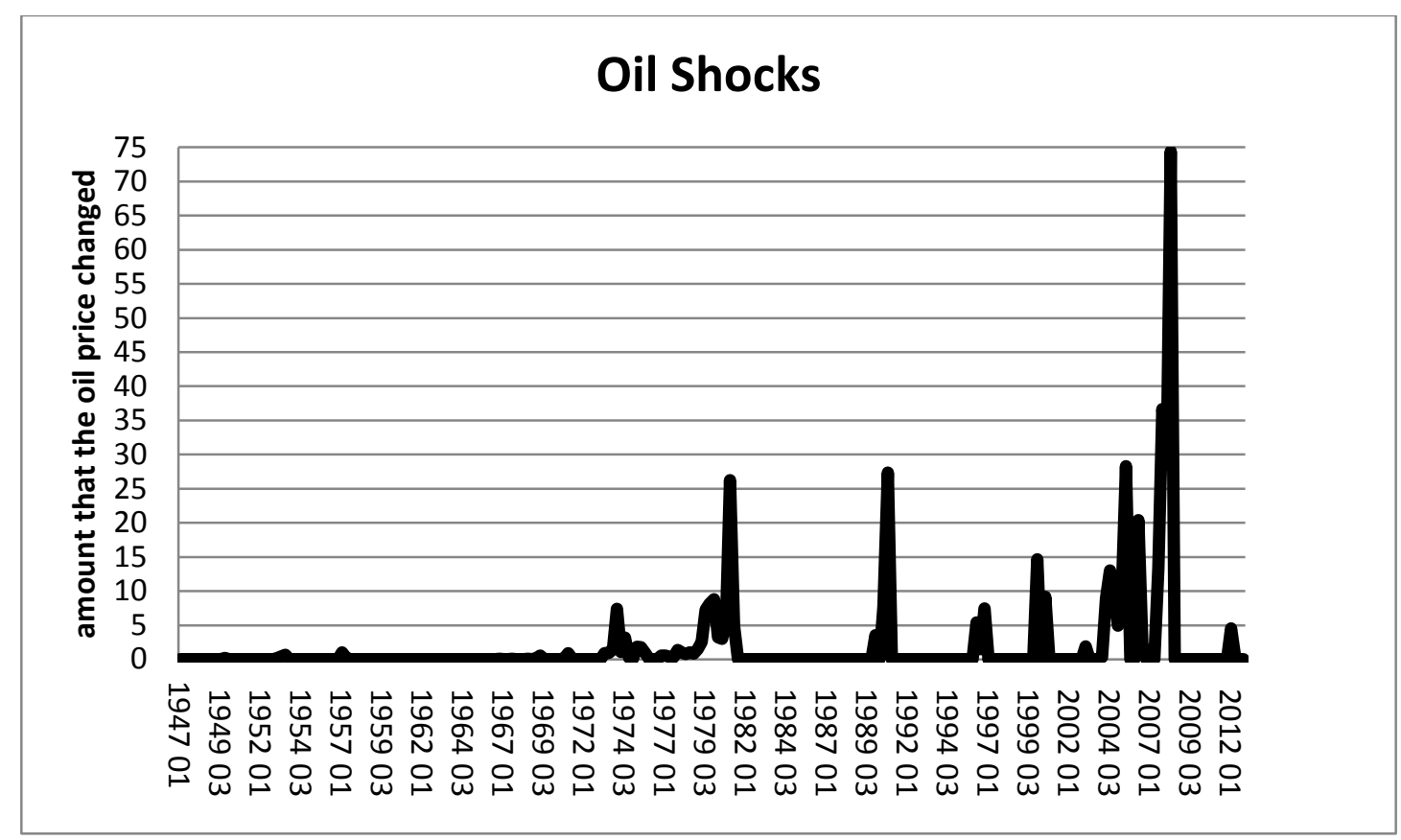

Figure 4: Oil shocks

Note: Oil shocks identified using the Hamilton (2003) method. An oil shock occurs when the current oil price exceeds the maximum price in the previous three years this measure the positive difference.

Table 2: Dates of oil shocks

\begin{tabular}{|c|}
\hline Date of oil shock \\
\hline 195303 \\
\hline 195701 \\
\hline 196902 \\
\hline 197101 \\
\hline 197401 \\
\hline 197502 \\
\hline 198001 \\
\hline 198101 \\
\hline 199004 \\
\hline 199604 \\
\hline 200001 \\
\hline 200403 \\
\hline 200503 \\
\hline 200802 \\
\hline 201201 \\
\hline
\end{tabular}




\subsection{U.S. Recessions and oil prices trends}

In a series of contributions, Hamilton (1983, 1996, 2005, and 2009) presented strong evidence indicating that increases in oil prices have been one of the primary causes of recessions in the United States. Over the past few decades, ten out of eleven U.S. recessions followed an increase in oil prices (an oil shock), except for the recession of 1960, as shown in Figure 4. Hamilton (1983 and 1985) mentioned that the primary catalysts for oil spikes were military conflicts such as the Suez Crisis, the Arab-Israel War, the Iranian Revolution, the Iran and Iraq War, and the Persian Gulf War. The largest percentage change in oil prices in most events like these has been due to OPEC or military conflicts in Middle East. 


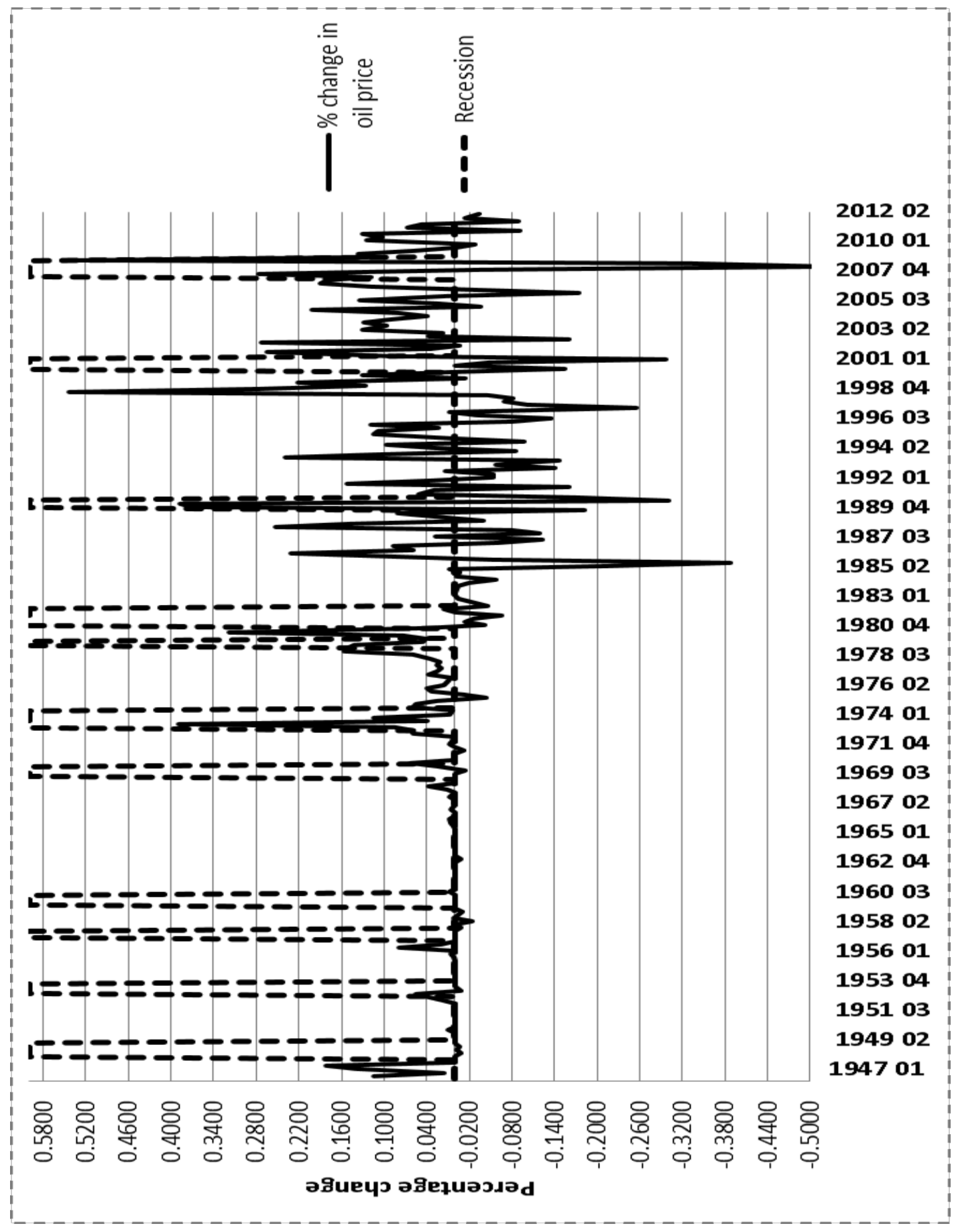

Figure 5 : Percentage change in producer prices index for oil price and U. S. Recessions Note: identify recession by National Bureau of Economic Research (NBER), and oil price by U.S. Energy Information Administration (EIA) 
Oil shock is a major factor that contributed to the collapse in automobile purchases, a slowdown in overall consumption spending, and deteriorating consumer sentiment in recessions. The result from an oil shock can cause low income and higher unemployment, which would also depress housing demand. For example Hamilton (2008) shows that a1\% reduction in real GDP growth translates into a $2.6 \%$ decrease in the demand for new houses.

During the first oil price increase (1949) within the data set, the rapid increase in oil price resulted from the fact that previous investments in production and transportation were inadequate to meet postwar needs. The second oil price increase (1953) took place because of Iranian nationalization ${ }^{10}$ and a strike by oil, coal, and steel workers in U.S. which resulted in an oil shortage, causing an increase in oil price. The third oil price increase (1957) was a result of the Suez Crisis ${ }^{11}$. The fourth recession (1960) is the most interesting because it was not derived from a spike in oil prices. Oil prices actually decreased during the 1960 U.S. recession. The fifth oil price increase (1970) preceded the secular decline in U.S. Reserves along with the strike of oil workers and the Libyan cutback in production (Libyan civil war) resulted in an upturn in oil prices. The sixth oil price increase (1974) resulted from stagnating U.S. production, the Yom Kipper War and the OPEC embargo, causing oil prices to quadruple. The seventh oil price increase (1980) follows the Iranian revolution which led to a significance upsurge in oil prices. The eighth oil price increase (1981) followed the Iranian revolution that led into the subsequent Iran-Iraq War, which in turn led to a significant

\footnotetext{
${ }^{10}$ Iranian nationalization is a political event that occurred in Iran in which the Iranian Prime Minister Mohammad Mosaddegh was overthrown. This situation caused Iran to explode with various problems that led to a long-term deterioration of Iran - United States relations. Iranian nationalization also interrupteds the production of oil since Iran was one of the most important countries to supply oil to the market.

${ }^{11}$ In order to trade between Asia, the Middle East, Europe and the U.S., these countries would normally use the canal, which directly links the Mediterranean to the Indian Ocean. However, France and Britain wanted to control the canal, not only for commercial shipping but also for colonial interests. The Suez Crisis was lasted for two years from 1956-1957.
} 
upsurge in oil prices. The ninth oil price increase (1990) was a result of the Persian Gulf War from the Iraq invasion of Kuwait. The tenth oil price increase (2000) occurred as OPEC cut oil production, triggering oil prices to go above average. The most recent oil price increase (2008) took place because of rapidly growing demand and tight capacity, crude outages in Nigeria, Iraq, and the North Sea, causing the oil prices to rise in June 2008 to the highest in history. All of these oil prices increases were followed by U.S. recessions.

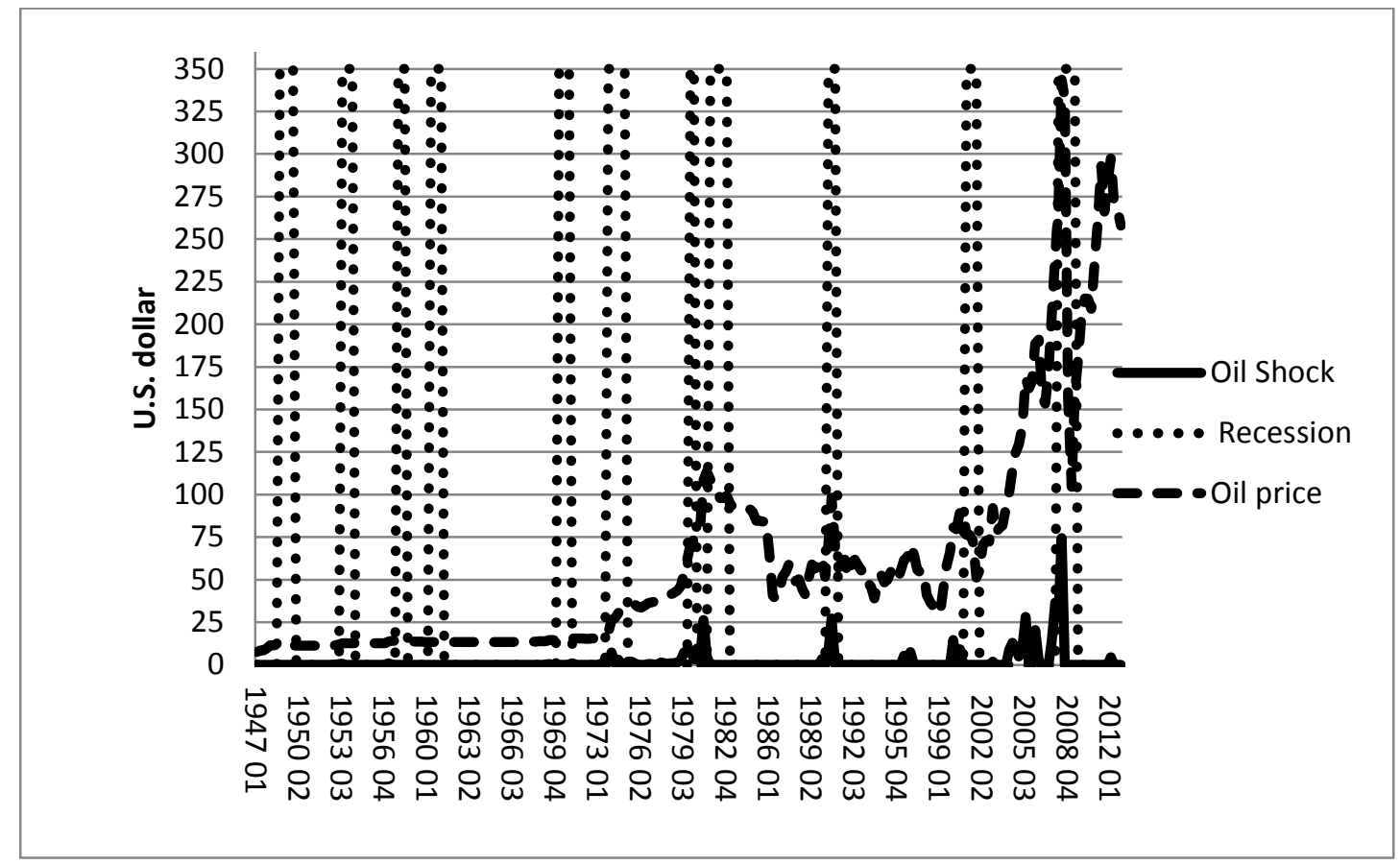

Figure 6: Producer price index for oil prices, U.S. recessions, and oil shocks

Note: Recessions identified by the National Bureau of Economic Research (NBER), oil shocks by using the Hamilton (2003) measure, and oil price from the U.S. Department of Commerce Bureau of Economic Analysis. 


\subsection{The Bry-Boschan method}

Roberts (2009) describes the method for identifying the turning points in a data series using the Bry- Boschan method. The process of identifying turning points using the Bry-Boschan method consists of six steps:

1. Replace any point of data that are more than 3.5 times the standard deviation of difference the original data and data that has been smoothed using a Spencer curve.

2. Smooth the adjusted data using a 12 month centered moving average smoothing then find highs and lows in this smoothed data over period from 12 months before to 5 months after each data point. Furthermore, enforce (deleted turning point if the rule is violated) the rule that peaks and troughs must alternate. The dates of the troughs and peaks are determined as TP1.

3. Compute a second Spencer curve of the adjusted data and determine the highs and lows (as TP2) using a +/- 5 month interval. Refine TP1 by selecting the highs and lows that are within the vicinity of turning points in a smoothed data series TP2 over a +/-5 month interval. Also, enforce the rules that peaks and troughs must alternate and cycles must have duration of at least 15 months. TP3 is the refined set of turning points.

4. Determine the months of cyclical dominance and use this to compute a centered moving average of the adjusted data using this period to find turning points as TP4. The TP5 results from the turning points identified in TP3 comparing against TP4 over +/- 5 month interval and enforcing the rule that troughs and peaks must alternate.

5. Identify actual highs and lows in the original unadjusted data that are within a $+/-5$ month interval of the turning points in TP5 and enforce the rules that peaks and troughs must alternate and troughs must have a lesser magnitude 
than peak. Only these dates of highs and lows in the original series are selected as turning points.

6. Lastly, using the original data series, the following step are iterated until no further changes to the turning points are made: enforce the rules that full cycles must have a duration of at least 15 months and peak and troughs must alternate; ensure that no turning points are closer than 5 months from the beginning or end of the data series and the first or last peak (trough) is higher (lower) than the first or last data point, and make sure that each phase has a duration of at least 6 months.

This process is used to determine the turning points in oil prices. The sample period of the analysis and model is from January 1947 to February 2013 on a monthly basis. Table 3 shows the results of identifying turning points in oil prices by using the Bry- Boschan method. Oil price peaks show the point in time when the highest oil prices are reached and oil prices begin to drop. Also, oil price troughs show the point where the lowest oil prices are and where the price will increase. Table 4 shows the results of turning points of GDP by using the Bry- Boschan. GDPs' peaks show the point where the economy expansion ends and economy contraction begins. Additionally, the GDPs' troughs show the point where an economic contraction end and cycles will start over with another economic expansion. Cycles consists of expansions, contractions, and full cycles, as well as the amplitude of price change during these periods. A peak is the end of the expansion or boom phase of the oil price and must follow a trough, which is the end of the contraction phase of oil prices. 
Table 3: Turning points in oil price identified using the Bry- Boschan method

\begin{tabular}{|c|c|}
\hline \multicolumn{2}{|c|}{ Oil price ( WPU oil price index cycles) } \\
\hline Peak & Trough \\
\hline January, 1948 & May, 1950 \\
\hline October,1950 & Septrmber,1952 \\
\hline June, 1953 & January, 1956 \\
\hline February, 1957 & November, 1960 \\
\hline April, 1961 & December, 1962 \\
\hline May, 1963 & January, 1966 \\
\hline April,1969 & July, 1970 \\
\hline January, 1971 & March, 1972 \\
\hline February, 1981 & May,1982 \\
\hline October,1982 & August, 1986 \\
\hline August, 1987 & November,1988 \\
\hline October, 1990 & February, 1994 \\
\hline July, 1994 & July, 1995 \\
\hline January, 1997 & December, 1998 \\
\hline November, 2000 & December, 2001 \\
\hline July, 2006 & January, 2007 \\
\hline July, 2008 & January, 2009 \\
\hline April, 2011 & June, 2012 \\
\hline
\end{tabular}

Table 4: Turning points in GDP identified using the Bry- Boschan method

\begin{tabular}{|c|c|}
\hline \multicolumn{2}{|c|}{ GDP } \\
\hline Peak & Trough \\
\hline November, 1948 & October, 1949 \\
\hline July, 1953 & May, 1954 \\
\hline August, 1957 & April, 1958 \\
\hline *April, 1960 & February, 1961 \\
\hline December, 1969 & November, 1970 \\
\hline$*$ November, 1973 & March, 1975 \\
\hline$* *$ January, 1980 & July, 1980 \\
\hline July, 1981 & November, 1982 \\
\hline July, 1990 & March, 1991 \\
\hline March, 2001 & November, 2001 \\
\hline December, 2007 & June, 2009 \\
\hline
\end{tabular}

* Not preceded by an oil price peak

** Not preceded by oil price peak, by cleaning occurred during an oil price run up 


\subsection{Turning point behavior of oil prices}

This paper focuses on testing the correlation between the oil prices and U.S. recessions. First, let us look at the pattern of U.S. recessions and oil prices so as to roughly describe their relationship, as shown in Figure 7.

Figure 7 shows the turning points in oil prices found using the Bry-Boschan procedure compared with the oil price and U.S. NBER reference cycles. Moreover, Figure 7 shows only ten oil price cycles but it shows eleven U.S. GDP cycles. Most of the oil prices cycles (dotted line) found by using Bry- Boschan method peak before U.S. recessions but some cycles might peak at the same time as with U.S. recessions. As shown in Figure 7, the oil price cycles often give early warning indication of GDP turning points, suggesting that oil prices have been a reliable indicator of GDP recessions. Figure 7 shows that oil price often expands before GDP recessions.

Table 5 compares the turning points of oil price peaks against GDP peaks. For example, oil price peaks ten months before the November 1948 GDP peak and oil price peaks one month before July 1953 peak. Thus, the last row of Table 5 shows the average number of months the oil prices turn before and after the GDP. As shown, the average number of months that oil prices lead U.S.GDP is five months. They often give early warning indicators of the GDP turning points, suggesting that oil prices peaks might be a reliable indicator of GDP recessions. 


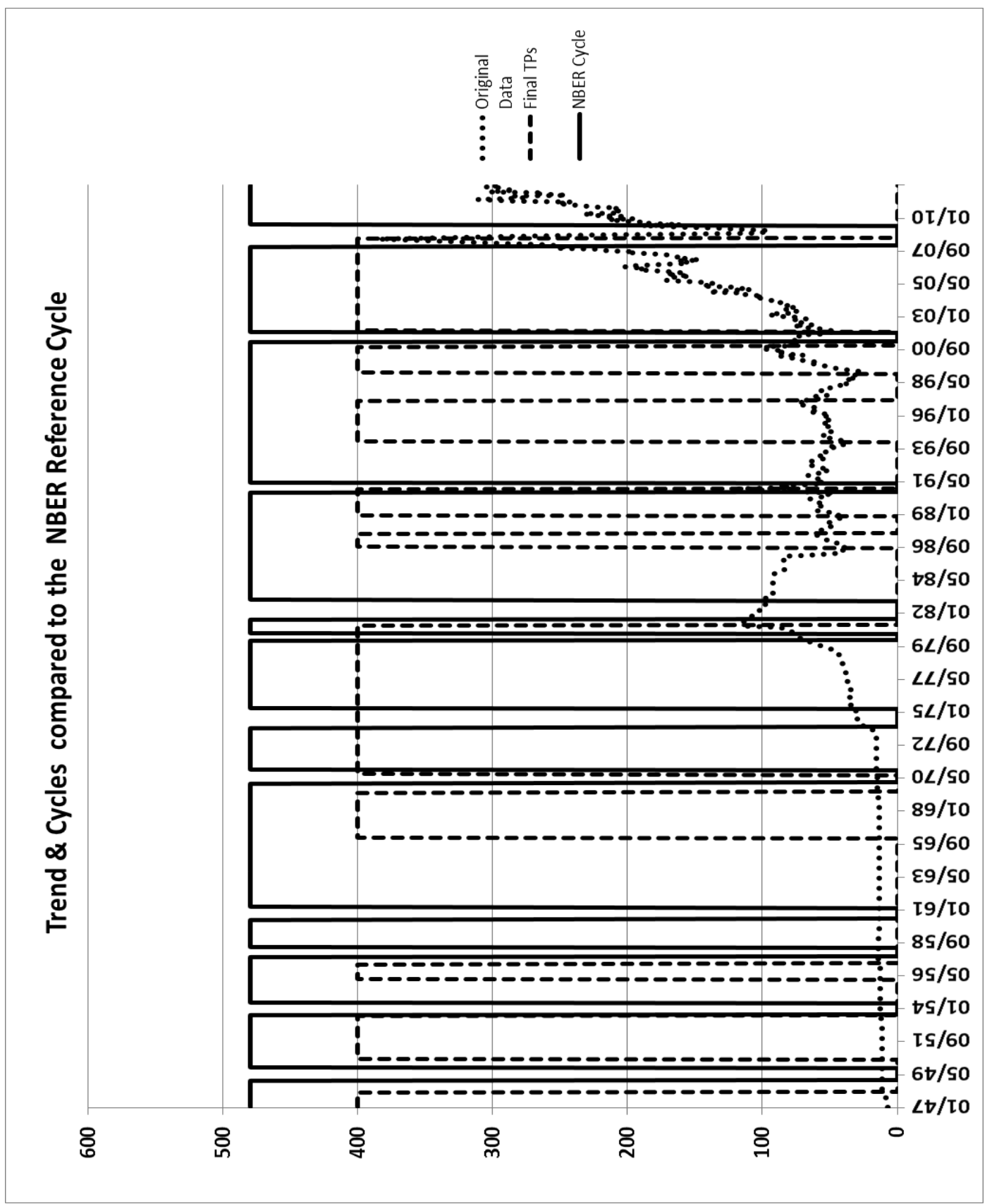

Figure 7: Producer price index for oil price, U.S. recessions from NBER, and oil price cycles

Note: The dashed line identifies the turning points of the business cycles (GDP) from the National Bureau of Economic Research (NBER); the solid line represents the oil prices, (WPU 0561 Oil price Index) from the U.S. Bureau of Labor Statistics, the circular dotted line indicates the oil price cycle found by using the Bry- Boschan method. 
Table 5: The result of turning point comparison by using the Bry - Boschan method to identity GDP and compared with the oil prices peaks

\begin{tabular}{|l|c|}
\hline \multicolumn{1}{|c|}{ GDP peaks } & $\begin{array}{c}\text { Number of months that oil price peaks lead (-), or } \\
\text { lag (+) the GDP peak. }\end{array}$ \\
\hline \multicolumn{1}{|c|}{ Oil prices } \\
\hline November 1948 peaks & -10 \\
\hline July 1953 peaks & -1 \\
\hline August 1957 peaks & -6 \\
\hline April 1960 peaks & ${ }^{*} 12$ \\
\hline December 1969 peaks & -8 \\
\hline November 1973 peaks & ${ }^{* *}-34$ \\
\hline January 1980 peaks & ${ }^{* *} 13$ \\
\hline July 1981 peaks & -5 \\
\hline July 1990 peaks & 3 \\
\hline March 2001 peaks & -4 \\
\hline December 2007 peaks & -17 \\
\hline Average & -5.18 \\
\hline
\end{tabular}

Table 6 compares the turning point of oil prices troughs against the GDP troughs. For example, oil prices turn seven months after the October 1949 troughs and oil prices turn twenty months after the May 1954 trough. Thus, the last row of Table 6 shows the average number of months the oil prices turn up after the GDP starts to recover. As shown, the average number of months that oil prices troughs lag the GDP troughs is seven months.

Table 6: The result of turning point comparison by Bry - Boschan method (GDP troughs) compared with the oil prices troughs

\begin{tabular}{|l|c|}
\hline \multicolumn{1}{|c|}{ GDP troughs } & $\begin{array}{c}\text { Number of months that oil price troughs lead (-), or } \\
\text { lag (+) the GDP trough }\end{array}$ \\
\hline \multicolumn{1}{|c|}{ Oil prices } \\
\hline October 1949 troughs & 7 \\
\hline May 1954 troughs & 20 \\
\hline April 1958 troughs & 31 \\
\hline February 1961 troughs & 22 \\
\hline November 1970 troughs & -4 \\
\hline March 1975 troughs & -36 \\
\hline July 1980 troughs & 22 \\
\hline November 1982 troughs & 6 \\
\hline March 1991 troughs & 35 \\
\hline November 2001 troughs & 1 \\
\hline June 2009 troughs & -29 \\
\hline Average & 6.82 \\
\hline
\end{tabular}




\subsection{Correlation between real U.S. GDP and real oil prices}

A correlation coefficient indicates the strength of the linear relationship between two variables. The values in Table 8 indicate the level of correlation between various lags of the variables. Table 8 also shows all strong positive correlation between the U.S. GDP from Economagic and oil prices come from the EIA in the form of quarterly data. These correlations are all positive which mean that U.S. GDP is moving in the same direction as oil prices.

Table 7: The correlation between GDP and oil price

\begin{tabular}{|l|c|c|c|c|c|}
\hline & & & & & \\
& Oil price & oil price (t-1) & oil price (t-2) & oil price (t-3) & oil price (t-4) \\
\hline GDP & 0.819 & 0.813 & 0.808 & 0.802 & 0.799 \\
\hline GDP (t-1) & 0.821 & 0.817 & 0.811 & 0.806 & 0.802 \\
\hline GDP (t-2) & 0.822 & 0.819 & 0.814 & 0.809 & 0.805 \\
\hline GDP (t-3) & 0.824 & 0.820 & 0.817 & 0.813 & 0.809 \\
\hline GDP (t-4) & 0.825 & 0.822 & 0.818 & 0.815 & 0.812 \\
\hline
\end{tabular}

\subsection{Correlation between WPU oil price index cycles and NBER U.S. cycle}

The values in Table 8 indicate the level of correlation between the following combinations of variables. The $r$ values in this report indicate the level of correlation between the combinations of different variables. Table 8 shows the weak positive correlation between the WPU oil price index cycle and NBER U.S. cycles, which mean that the WPU oil price index cycles are moving in the same direction at the NBER U.S. cycles. Even though the WPU oil price index cycle is 
positive, the relationship is very weak. Also, the NBER US cycles have a higher correlation when the WPU Oil Price Index cycle moves back in different time periods. Moreover, in order for the $r$ numbers to be statistically significant, the $r$ numbers need to be greater than 0.12 , but Table 8 show no sign of significant correlation between the WPU oil price index cycles and NBER U.S. cycles.

Table 8: Correlation between the WPU oil price index cycles and NBER US cycles

\begin{tabular}{|l|c|c|c|c|c|}
\hline & $\begin{array}{c}\text { WPU Oil } \\
\text { Price } \\
\text { Index } \\
\text { cycles }\end{array}$ & $\begin{array}{c}\text { WPU Oil } \\
\text { Price } \\
\text { Index } \\
\text { cycles } \\
\text { (t-1) }\end{array}$ & $\begin{array}{c}\text { WPU Oil } \\
\text { Price } \\
\text { Index } \\
\text { cycles } \\
\text { (t-2) }\end{array}$ & $\begin{array}{c}\text { WPU Oil } \\
\text { Price } \\
\text { Index } \\
\text { cycles } \\
(\mathbf{t}-3)\end{array}$ & $\begin{array}{c}\text { WPU Oil } \\
\text { Price } \\
\text { Index } \\
\text { cycles } \\
\text { (t-4) }\end{array}$ \\
\hline NBER US cycles & 0.076 & 0.083 & 0.090 & 0.097 & 0.097 \\
\hline NBER US cycles (t-1) & 0.069 & 0.076 & 0.083 & 0.090 & 0.097 \\
\hline NBER US cycles (t-2) & 0.055 & 0.069 & 0.076 & 0.083 & 0.090 \\
\hline NBER US cycles (t-3) & 0.055 & 0.055 & 0.069 & 0.076 & 0.083 \\
\hline NBER US cycles (t-4) & 0.048 & 0.055 & 0.055 & 0.069 & 0.076 \\
\hline
\end{tabular}

\subsection{Reproduction of the Hamilton model}

Regression is one of methods that have been used to test for a significant relationship between oil prices and a recession. Hamilton used a regression of lagged changes in GDP growth rates explained by lagged logarithmic change in nominal oil prices from 1949II to 2005II. He found that the coefficient on the fourth lag of oil prices is negative and highly statistically significant as shown in below: 


$$
\begin{aligned}
& \text { Model 1: Hamilton }
\end{aligned}
$$

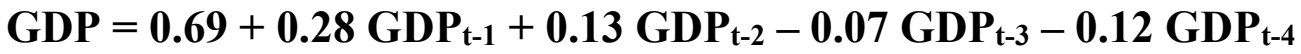

$$
\begin{aligned}
& \begin{array}{lllll}
(0.11) & (0.07) & (0.07) & (0.07) & (0.07)
\end{array} \\
& \text { T-score } \\
& \text { (4) } \\
& \begin{array}{llll}
(0.006) & (0.006) & (0.006) & (0.006)
\end{array}
\end{aligned}
$$
T-score
(1)
$(0.33)$

Where GDP $=$ GDP growth rates

$$
\text { Oil }=\text { nominal oil prices }
$$

Hamilton did not report the statics (N, R-Square, Adjusted R -Square, Fstatic) result behind the regression expect the equation that shows.

\section{Model 2: My result}

$$
\begin{array}{lllll}
\mathbf{G D P}= & \mathbf{2 . 7 6}+\mathbf{0 . 3 0} \mathbf{G D P}_{\mathrm{t}-\mathbf{1}}+ & \mathbf{0 . 1 4} \mathbf{G D P}_{\mathrm{t}-2}- & \mathbf{0 . 0 9 9} \mathbf{G D P}_{\mathrm{t}-\mathbf{3}}-\mathbf{0 . 0 9 7} \mathbf{G D P}_{\mathrm{t}-\mathbf{4}} \\
(6.38) & (4.41) & (2.01) & (-1.42) & (-1.45) \\
\text { T-score } & (0.68) & (0.07) & (0.07) & (0.067)
\end{array}
$$

$$
-1.23 \text { Oil }_{t-1}-4.14 \text { Oil }_{t-2}+1.08 \text { Oil }_{t-3}-4.45 \text { Oil }_{t-4}
$$

$$
(-0.45) \quad(-1.5) \quad(0.39) \quad(-1.63)
$$

T-score (2.73) (2.76) (2.77)

$\mathrm{N}=226, \quad \mathrm{R}^{-}$square $=0.162, \quad$ Adjusted R- square $=0.131, \quad$ F-statically $=5.226$ 
However, I used the same data and the same method to attempt to duplicate the results from Hamilton but could not obtain his results.

The result from Hamilton shows that all the GDP variables are significant and none of oil variables are significant except the fourth lag of oil prices. Also, the majority of the oil prices variables have a negative sign which show that oil prices and GDP move in opposite direction. My results shows that all GDP variables are not significant and all oil prices variables are significant. Also, most of the oil prices variables have a negative sign, except for the third lag of oil prices that has a positive sign. Except for the third lag in oil prices, we can conclude that the direction of oil price moves proceeded and are in the opposite direction with GDP. This result supports the idea that oil shocks preceded recessions. The results from Model 1 come from Hamilton. Model 2 are my results from using the same set of data and time frame. It is not known why Hamilton's result cannot be duplicated

\subsection{Granger Causality tests}

Regression analysis typically cannot prove causality between oil prices and U.S. recessions, but regression can give evidence of a relationship. The Granger causality test determines if one time series variable consistently and predictably changes before another variable, which can be used to indicate causality. Granger causality is a useful instrument for forecasting purpose and shows which variable precedes another. ${ }^{12}$ These tests are useful to show if an oil price change precedes recessions. There are a number of different tests for Granger causality, but this paper uses eight lags of oil price and eight lags of GDP.

\footnotetext{
${ }^{12}$ Hamilton (1983, 1996, 2003 and 2003) conducted the Granger causality test of whether oil price uncertainty has a significant effect on output.
} 
If an oil price change Granger causes a U.S. recession, I would run a simple regression for the coefficients with the formula below:

$$
\begin{aligned}
\mathrm{GDP}= & \mathrm{Bo}+\mathrm{B}_{1} \mathrm{GDP}_{\mathrm{t}-\mathrm{1}}+\mathrm{B}_{2} \mathrm{GDP}_{\mathrm{t}-2}+\mathrm{B}_{3} \mathrm{GDP}_{\mathrm{t}-3}+\mathrm{B}_{4} \mathrm{GDP}_{\mathrm{t}-4}+\mathrm{B}_{5} \mathrm{GDP}_{\mathrm{t}-5}+\mathrm{B}_{6} \mathrm{GDP}_{\mathrm{t}-6} \\
& +\mathrm{B}_{7} \mathrm{GDP}_{\mathrm{t}-7}+\mathrm{B}_{8} \mathrm{GDP}_{\mathrm{t}-8}-\alpha_{1} \mathrm{Oil}_{\mathrm{t}-1}-\alpha_{2} \mathrm{Oil}_{\mathrm{t}-2}-\alpha_{3} \mathrm{Oil}_{\mathrm{t}-3}-\alpha_{4} \mathrm{Oil}_{\mathrm{t}-4}-\alpha_{5} \mathrm{Oil}_{\mathrm{t}-5} \\
& -\alpha_{6} \mathrm{Oil}_{\mathrm{t}-6}-\alpha_{7} \mathrm{Oil}_{\mathrm{t}-7}-\alpha_{8} \mathrm{Oil}_{\mathrm{t}-8}+\varepsilon_{\mathrm{t}}
\end{aligned}
$$

From the regression, and then testing for the null hypothesis (Ho), which is when the as are jointly equal to zero. The F-test is used for this joint hypothesis test. If we reject the null hypothesis, it indicates that oil price change Granger causes recessions in the U.S. This procedure can be reversed by making the oil price the dependent variable and GDP the independent variable to establish if GDP Granger causes oil prices fluctuations, using the formula below:

$$
\begin{aligned}
& \text { Oil }=\text { Bo }+ \text { B }_{1} \mathrm{Oil}_{\mathrm{t}-1}+\mathrm{B}_{2} \mathrm{Oil}_{\mathrm{t}-2}+\mathrm{B}_{3} \mathrm{Oil}_{\mathrm{t}-3}+\mathrm{B}_{4} \mathrm{Oil}_{\mathrm{t}-4}+\mathrm{B}_{5} \mathrm{Oil} \mathrm{t}_{\mathrm{t}-5}+\mathrm{B}_{6} \mathrm{Oil} \mathrm{l}_{\mathrm{t}-6}+\mathrm{B}_{7} \mathrm{Oil} \mathrm{l}_{\mathrm{t}-7} \\
& +\mathrm{B}_{8} \mathrm{Oil}_{\mathrm{t}-\mathrm{z}^{-}} \alpha_{1} \mathrm{GDP}_{\mathrm{t}-1}-\alpha_{2} \mathrm{GDP}_{\mathrm{t}-2}-\alpha_{3} \mathrm{GDP}_{\mathrm{t}-3}-\alpha_{4} \mathrm{GDP}_{\mathrm{t}-\mathrm{4}}-\alpha_{5} \mathrm{GDP}_{\mathrm{t}-5}-
\end{aligned}
$$

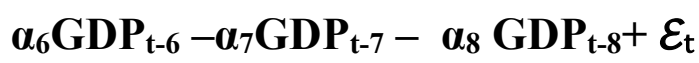

Table 9 presents the F-statistics of the Granger causality test for each of the equations in the sample period from January 1949 to December 2012 on a quarterly basis, which appendix D shows F- statistics calculation. The significance of the equation as a whole is determined by verifying that the F-statistic is greater than F-critical. Also, if the F-statistic is greater than F-critical then I am able to identify that the independent variable is Granger causing the dependent variable to move. 
Table 9: Granger Causality F-statistics (5\% percent level of significance)

\begin{tabular}{|c|c|c|c|}
\hline Sample & 1949II -2012IV & Oil prices ---> Recession & Recession --->Oil prices \\
\hline \multicolumn{2}{|c|}{ F-statistics } & 1.95 & 0.056 \\
\hline \multicolumn{2}{|c|}{ F-critical } & 1.94 & 1.94 \\
\hline \multicolumn{2}{|c|}{ Conclusion } & $\begin{array}{l}\text { Oil prices do Granger } \\
\text { causes U.S. recession }\end{array}$ & $\begin{array}{l}\text { U.S. recessions do not } \\
\text { Granger causes oil prices }\end{array}$ \\
\hline
\end{tabular}

Table 9 concludes that oil prices change do Granger causes U.S. recession but U.S. recessions do not Granger cause oil prices changes. Based on the evidence on the Granger Causality test, we can conclude that the U.S. recessions are caused by oil prices increases. The specific information used can be found in Appendix C. 


\section{Chapter 6 Conclusion}

This paper tests for a relationship between oil price changes and economic activity, and it attempts to address the question: do increases in oil prices (oil shocks) precede a recession in the U.S.? In order to answer this question several tests were made. The binary cyclical indicator tested the turning point of oil prices compared with those of GDP, finding that oil prices almost always increase an average of five months before a recession. This suggests that an oil shock might occur before a recession. It also indicates that increases in oil prices may be reliable indicators of the U.S. having a recession.

The correlation test shows that WPU oil price index cycles and NBER U.S. cycles are a weak positively correlated, which mean that the WPU oil price index cycles move in the same direction as the NBER US cycles. Even though the WPU oil price index cycle is positive, the relationship is very weak and is somewhat insignificant. The NBER US cycles have a higher correlation when the WPU Oil Price Index cycles move back in different time period. The correlation test also is an indication of a strong positive correlation between the U.S. GDP, and oil prices. This means that the U.S. GDP often moves in the same direction as oil prices.

The Granger causality test shows that oil prices Granger cause the U.S. recessions, indicating that the oil price is a useful tool to indicate the U.S. cycle. While, the result of the Granger causality shows that the U.S. recession just occurred at the same time as the oil price increase.

Combining this analysis from the literature, there are several other issues: explanations that the spike in oil prices is one major cause of recession. There is some evidence that the effect of oil price changes on the macroeconomy may not be linear; a negative effect of a spike up in oil prices is more pronounced than the 
positive effect of the same size of a decrease in oil prices. Also, the literature concludes that significant increases in oil prices (oil shocks) result in slower GDP growth and are a contributing factor of U.S. recessions, a higher unemployment rate, and increases in the cost of living. Some economists argue that oil shocks are not just coincidently happening at the same time as recessions. Furthermore, all but one of the U.S. recessions since World War II has been proceeded by an increase in the price of oil, the exception being the minor recession of 1960. Therefore, it is worthwhile to continue investigating this relationship between oil prices and the U.S. economic activity by reproducing Hamilton's results. We should also try to come with difference methods beside what has been shown in the research to predict the relationship between oil prices and U.S. recessions. 


\section{References}

AGUIAR-CONRARIA, LUÍS, \& Wen, Yi. (2007). Understanding the large negative impact of oil shocks. Journal of Money, Credit and Banking, 39(4), 925-944.

Balke, Nathan S, Brown, Stephen PA, \& Yücel, Mine K. (2010). Oil price shocks and US economic activity: an international perspective. Federal Reserve Bank of Dallas, Dal $\$$ las Fed WP, 1003, 43.

Banerjee, Anindya, \& Marcellino, Massimiliano. (2006). Are there any reliable leading indicators for US inflation and GDP growth? International Journal of Forecasting, 22(1), 137-151.

Bernanke, Ben S, Gertler, Mark, Watson, Mark, Sims, Christopher A, \& Friedman, Benjamin M. (1997). Systematic monetary policy and the effects of oil price shocks. Brookings papers on economic activity, 1997(1), 91-157.

Blanchard, Olivier J, \& Gali, Jordi. (2007). The Macroeconomic Effects of Oil Shocks: Why are the 2000s so different from the 1970s? : National Bureau of Economic Research.

Brown, Stephen, \& Yücel, Mine K. (2002). Energy prices and aggregate economic activity: an interpretative survey. The Quarterly Review of Economics and Finance, 42(2), 193-208.

Burbidge, John, \& Harrison, Alan. (1984). Testing for the effects of oil-price rises using vector autoregressions. International Economic Review, 25(2), 459-484.

Carstensen, Kai, Elstner, Steffen, \& Paula, Georg. (2011). How strongly did the 2007/08 oil price hike contribute to the subsequent recession? : CESifo working paper: Monetary Policy and International Finance.

Darby, Michael R. (1982). The price of oil and world inflation and recession. The American Economic Review, 72(4), 738-751.

Economagic, LLC. (2002). Economic Time Series Page. Online data source, www. economagic. com. 
EIA, US. (2011). Annual energy review. Energy Information Administration, US Department of Energy: Washington, DC www. eia. doe. gov/emeu/aer.

Gisser, Micha, \& Goodwin, Thomas H. (1986). Crude oil and the macroeconomy: Tests of some popular notions: Note. Journal of Money, Credit and Banking, 18(1), 95103.

Guo, Hui, \& Kliesen, Kevin L. (2005). Oil price volatility and US macroeconomic activity. REVIEW-FEDERAL RESERVE BANK OF SAINT LOUIS, 87(6), 669.

Hamilton, James D. (1983). Oil and the macroeconomy since World War II. The Journal of Political Economy, 228-248.

Hamilton, James D. (1996). This is what happened to the oil price-macroeconomy relationship. Journal of Monetary Economics, 38(2), 215-220.

Hamilton, James D. (2003). What is an oil shock? Journal of econometrics, 113(2), 363398.

Hamilton, James D. (2005). Oil and the Macroeconomy. The New Palgrave Dictionary of Economics Palgrave Macmillan, London. Available online at http://www. dictionaryofeconomics. com/dictionary. Jiménez-Rodríguez, Rebeca and Marcelo Sánchez, 201-228.

Hamilton, James D. (2008). Understanding crude oil prices: National Bureau of Economic Research.

Hamilton, James D. (2009). Causes and Consequences of the Oil Shock of 2007-08: National Bureau of Economic Research.

Hamilton, James D. (2012). Oil Prices, exhaustible resources, and economic growth: National Bureau of Economic Research.

Hamilton, James D, \& Herrera, Ana Maria. (2004). Comment: Oil shocks and aggregate macroeconomic behavior: The role of monetary policy. Journal of Money, Credit and Banking, 265-286.

Hooker, Mark A. (1996). What happened to the oil price-macroeconomy relationship? Journal of Monetary Economics, 38(2), 195-213. 
Jones, Donald W, Leiby, Paul N, \& Paik, Inja K. (2004). Oil price shocks and the macroeconomy: what has been learned since 1996. The Energy Journal, 1-32.

Katayama, Munechika. (2007). Declining Effects of Oil\% price Shocks. University of California, San Diego, Job Market Paper.

Kilian, Lutz. (2008). Exogenous oil supply shocks: how big are they and how much do they matter for the US economy? The Review of Economics and Statistics, 90(2), 216-240.

Kilian, Lutz. (2009). Comment on 'Causes and Consequences of the Oil Shock of 200708'by James D. Hamilton. Brookings Papers on Economic Activity, 1, 267-278.

Kilian, Lutz, \& Park, Cheolbeom. (2009). THE IMPACT OF OIL PRICE SHOCKS ON THE US STOCK MARKET*. International Economic Review, 50(4), 1267-1287.

Korhonen, likka, \& Ledyaeva, Svetlana. (2010). Trade linkages and macroeconomic effects of the price of oil. Energy Economics, 32(4), 848-856.

Lee, Kiseok, Ni, Shawn, \& Ratti, Ronald A. (1995). Oil shocks and the macroeconomy: the role of price variability. The Energy Journal, 39-56.

Mork, Knut Anton. (1989). Oil and the macroeconomy when prices go up and down: an extension of Hamilton's results. The Journal of Political Economy, 97(3), 740-744.

Mork, Knut Anton, Olsen, Øystein, \& Mysen, Hans Terje. (1994). Macroeconomic responses to oil price increases and decreases in seven OECD countries. The Energy Journal, 19-35.

Peter Ferderer, J. (1997). Oil price volatility and the macroeconomy. Journal of Macroeconomics, 18(1), 1-26.

Rasmussen, Tobias, \& Roitman, Agustin. (2011). Oil Shocks in a Global Perspective: Are they Really that Bad? IMF Working Papers, 1-29.

Roberts, Mark C. (2009). Duration and characteristics of metal price cycles. Resources Policy, 34(3), 87-102.

Sadorsky, Perry. (1999). Oil price shocks and stock market activity. Energy Economics, 21(5), 449-469. 
Segal, Paul. (2011). Oil price shocks and the macroeconomy. Oxford Review of Economic Policy, 27(1), 169-185.

Studenmund, Arnold Harwood, \& Cassidy, Henry J. (2001). Using econometrics: AddisonWesley.

Tang, Weiqi, Wu, Libo, \& Zhang, ZhongXiang. (2010). Oil price shocks and their short-and long-term effects on the Chinese economy. Energy Economics, 32, S3-S14. 


\section{Appendix A: Data}

\begin{tabular}{|c|c|c|c|c|c|}
\hline & $\begin{array}{l}\text { Oil price } \\
\text { From U.S. } \\
\text { DCB of } \\
\text { Economic } \\
\text { Analysis }\end{array}$ & $\begin{array}{c}\text { WPU Oil } \\
\text { Price Index } \\
\text { cycles from } \\
\text { Bry- } \\
\text { Boschan }\end{array}$ & $\begin{array}{c}\text { GDP in } \\
\text { billions of } \\
\text { chained } 2005 \\
\text { dollars from } \\
\text { U.S. DCB of } \\
\text { Economic } \\
\text { Analysis }\end{array}$ & $\begin{array}{l}\text { GDP Growth Rate } \\
\text { from Economagic }\end{array}$ & $\begin{array}{l}1=\text { expansion } \\
0=\text { recession }\end{array}$ \\
\hline 194901 & 11.40 & 0 & 1770.7 & -5.45 & 0 \\
\hline 194902 & 11.37 & 0 & 1768 & -1.45 & 0 \\
\hline 194903 & 11.30 & 0 & 1766.5 & 4.56 & 0 \\
\hline 194904 & 11.30 & 0 & 1793.3 & -3.69 & 1 \\
\hline 195001 & 11.30 & 0 & 1821.8 & 17.15 & 1 \\
\hline 195002 & 11.30 & 1 & 1855.3 & 12.75 & 1 \\
\hline 195003 & 11.30 & 1 & 1865.3 & 16.60 & 1 \\
\hline 195004 & 11.40 & 0 & 1868.2 & 7.23 & 1 \\
\hline 195101 & 11.40 & 0 & 1842.2 & 5.14 & 1 \\
\hline 195102 & 11.40 & 0 & 1835.5 & 6.81 & 1 \\
\hline 195103 & 11.40 & 0 & 1856.1 & 8.21 & 1 \\
\hline 195104 & 11.40 & 0 & 1838.7 & 0.68 & 1 \\
\hline 195201 & 11.40 & 0 & 1913 & 4.09 & 1 \\
\hline 195202 & 11.40 & 0 & 1971.2 & 0.43 & 1 \\
\hline 195203 & 11.40 & 0 & 2048.4 & 2.71 & 1 \\
\hline 195204 & 11.40 & 1 & 2084.4 & 13.87 & 1 \\
\hline 195301 & 11.60 & 1 & 2110.7 & 7.70 & 1 \\
\hline 195302 & 12.03 & 1 & 2145.7 & 3.06 & 1 \\
\hline 195303 & 12.70 & 0 & 2188.5 & -2.41 & 0 \\
\hline 195304 & 12.60 & 0 & 2192.2 & -6.19 & 0 \\
\hline 195401 & 12.60 & 0 & 2214.3 & -1.89 & 0 \\
\hline 195402 & 12.60 & 0 & 2216.7 & 0.50 & 0 \\
\hline 195403 & 12.60 & 0 & 2231.6 & 4.58 & 1 \\
\hline 195404 & 12.60 & 0 & 2305.3 & 8.26 & 1 \\
\hline 195501 & 12.60 & 0 & 2348.4 & 12.01 & 1 \\
\hline 195502 & 12.60 & 0 & 2366.2 & 6.80 & 1 \\
\hline
\end{tabular}




\begin{tabular}{ll}
195503 & 12.60 \\
195504 & 12.60 \\
195601 & 12.60 \\
195602 & 12.63 \\
195603 & 12.70 \\
195604 & 12.73 \\
195701 & 13.73 \\
195702 & 14.00 \\
195703 & 14.00 \\
195704 & 14.00 \\
195801 & 14.00 \\
195802 & 14.00 \\
195803 & 13.90 \\
195804 & 13.90 \\
195901 & 13.57 \\
195902 & 13.60 \\
195903 & 13.53 \\
195904 & 13.40 \\
196001 & 13.40 \\
196002 & 13.40 \\
196003 & 13.40 \\
196004 & 13.40 \\
196101 & 13.40 \\
196102 & 13.50 \\
196103 & 13.50 \\
196104 & 13.50 \\
196201 & 13.50 \\
196202 & 13.50 \\
196203 & 13.50 \\
196204 & 13.50 \\
196301 & 13.50 \\
196302 & 13.50 \\
196303 & 13.50 \\
196404 & 13.40 \\
\hline 13.40 \\
\hline 196404
\end{tabular}

2351.8
2314.6
2303.5
2306.4
2332.4
2379.1

$5.44 \quad 1$

$2.25 \quad 1$

$-1.80 \quad 1$

$3.17 \quad 1$

$\begin{array}{ll}-0.50 & 1\end{array}$

$6.71 \quad 1$

2447.7

$2.48 \quad 1$

2488.1

$\begin{array}{ll}-0.97 & 1\end{array}$

2521.4

$3.91 \quad 1$

2535.5

$-4.150$

2523.9

$-10.39$

2.47

9.72

9.65

8.33

10.50

$-0.47$

1.41

9.28

$-1.86$

0.65

$-5.03$

2.40

7.69

6.62

8.39

7.37

4.49

3.75

0.99

5.33

5.10

7.75

3.08

9.27 


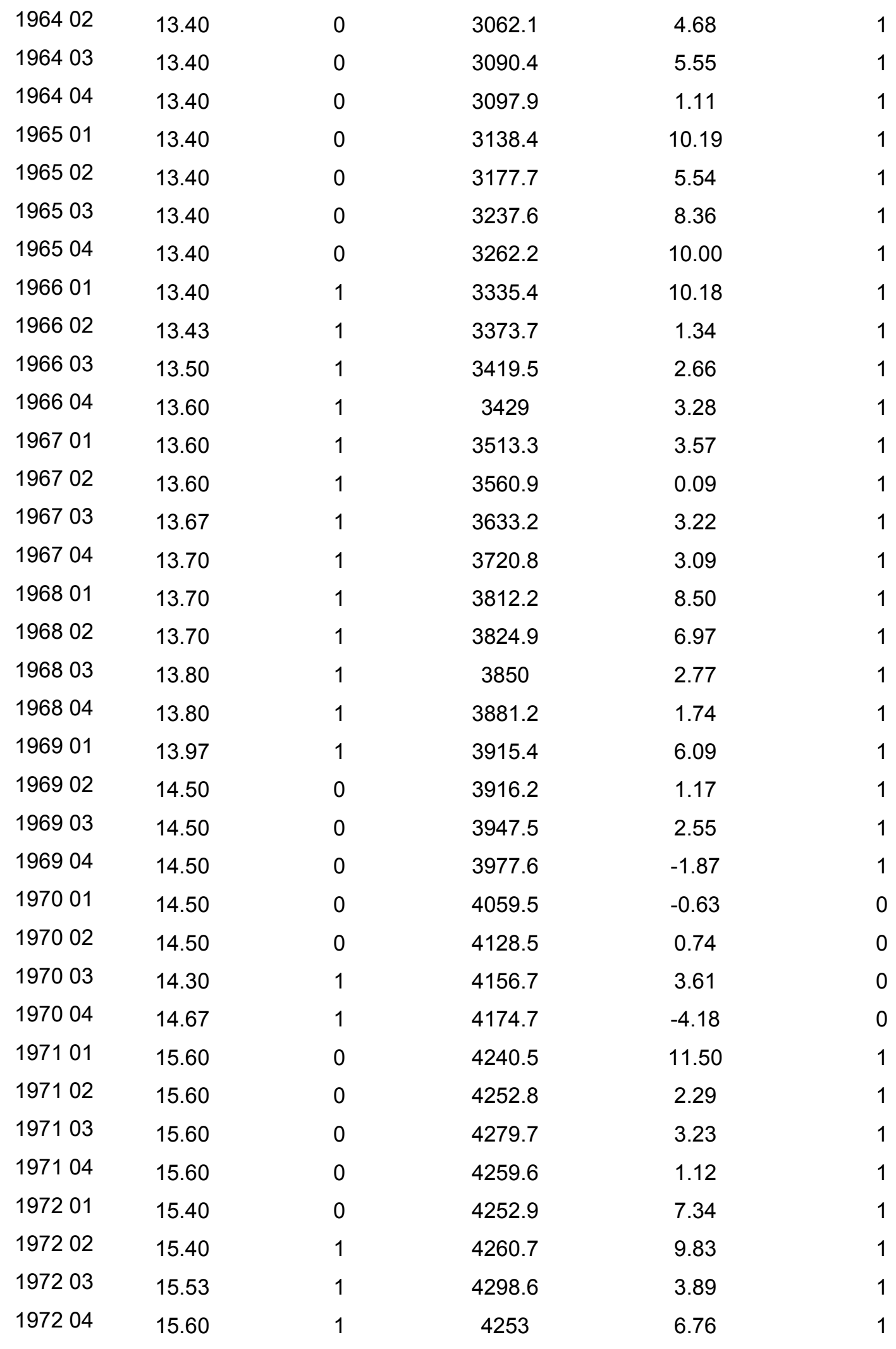




\begin{tabular}{|c|c|c|c|c|}
\hline 197301 & 15.63 & 1 & 4370.3 & 10.63 \\
\hline 197302 & 16.57 & 1 & 4395.1 & 4.71 \\
\hline 197303 & 17.53 & 1 & 4430.2 & -2.12 \\
\hline 197304 & 19.03 & 1 & 4442.5 & 3.87 \\
\hline 197401 & 26.43 & 1 & 4521.9 & -3.46 \\
\hline 197402 & 27.50 & 1 & 4629.1 & 1.03 \\
\hline 197403 & 30.67 & 1 & 4673.5 & -3.89 \\
\hline 197404 & 30.90 & 1 & 4750.5 & -1.57 \\
\hline 197501 & 31.00 & 1 & 4872 & -4.78 \\
\hline 197502 & 32.83 & 1 & 4928.4 & 3.09 \\
\hline 197503 & 34.63 & 1 & 4902.1 & 6.91 \\
\hline 197504 & 35.53 & 1 & 4948.8 & 5.33 \\
\hline 197601 & 34.00 & 1 & 4905.4 & 9.40 \\
\hline 197602 & 33.57 & 1 & 4918 & 3.05 \\
\hline 197603 & 34.70 & 1 & 4869.4 & 1.97 \\
\hline 197604 & 36.10 & 1 & 4850.2 & 2.94 \\
\hline 197701 & 36.67 & 1 & 4791.2 & 4.72 \\
\hline 197702 & 37.03 & 1 & 4827.8 & 8.19 \\
\hline 197703 & 37.27 & 1 & 4909.1 & 7.35 \\
\hline 197704 & 38.63 & 1 & 4973.3 & -0.09 \\
\hline 197801 & 39.63 & 1 & 5086.3 & 1.37 \\
\hline 197802 & 40.40 & 1 & 5124.6 & 16.69 \\
\hline 197803 & 41.40 & 1 & 5149.7 & 3.98 \\
\hline 197804 & 42.27 & 1 & 5187.1 & 5.40 \\
\hline 197901 & 43.73 & 1 & 5247.3 & 0.67 \\
\hline 197902 & 46.30 & 1 & 5351.6 & 0.37 \\
\hline 197903 & 53.57 & 1 & 5447.3 & 2.91 \\
\hline 197904 & 61.70 & 1 & 5446.1 & 1.11 \\
\hline 198001 & 70.50 & 1 & 5464.7 & 1.29 \\
\hline 198002 & 73.77 & 0 & 5679.7 & -7.95 \\
\hline 198003 & 76.80 & 0 & 5735.4 & -0.74 \\
\hline 198004 & 82.40 & 0 & 5811.3 & 7.60 \\
\hline 198101 & 108.63 & 0 & 5821 & 8.58 \\
\hline 198102 & 113.57 & 0 & 5826.4 & -3.16 \\
\hline 198103 & 108.77 & 0 & 5868.3 & 4.95 \\
\hline
\end{tabular}




\begin{tabular}{|c|c|c|c|c|}
\hline 198104 & 107.33 & 0 & 5884.5 & -4.89 \\
\hline 198201 & 104.63 & 0 & 5903.4 & -6.41 \\
\hline 198202 & 97.90 & 0 & 5782.4 & 2.18 \\
\hline 198203 & 97.97 & 1 & 5771.7 & -1.53 \\
\hline 198204 & 99.50 & 1 & 5878.4 & 0.31 \\
\hline 198301 & 95.03 & 0 & 6000.6 & 5.06 \\
\hline 198302 & 92.43 & 0 & 5952.7 & 9.30 \\
\hline 198303 & 92.10 & 0 & 6025 & 8.13 \\
\hline 198304 & 92.07 & 0 & 5950 & 8.53 \\
\hline 198401 & 92.10 & 0 & 5852.3 & 7.99 \\
\hline 198402 & 91.87 & 0 & 5884 & 7.08 \\
\hline 198403 & 91.53 & 0 & 5861.4 & 3.94 \\
\hline 198404 & 89.77 & 0 & 5866 & 3.30 \\
\hline 198501 & 84.63 & 0 & 5938.9 & 3.82 \\
\hline 198502 & 84.50 & 0 & 6072.4 & 3.43 \\
\hline 198503 & 84.00 & 0 & 6192.2 & 6.40 \\
\hline 198504 & 84.70 & 0 & 6320.2 & 3.07 \\
\hline 198601 & 66.40 & 0 & 6442.8 & 3.90 \\
\hline 198602 & 40.67 & 0 & 6554 & 1.62 \\
\hline 198603 & 38.57 & 0 & 6617.7 & 3.91 \\
\hline 198604 & 42.00 & 1 & 6671.6 & 1.95 \\
\hline 198701 & 51.70 & 1 & 6734.5 & 2.23 \\
\hline 198702 & 54.77 & 1 & 6791.5 & 4.32 \\
\hline 198703 & 59.57 & 1 & 6897.6 & 3.51 \\
\hline 198704 & 55.87 & 0 & 6950 & 7.02 \\
\hline 198801 & 49.00 & 0 & 7016.8 & 2.08 \\
\hline 198802 & 50.40 & 0 & 7045 & 5.24 \\
\hline 198803 & 44.43 & 0 & 7112.9 & 2.08 \\
\hline 198804 & 40.93 & 0 & 7147.3 & 5.45 \\
\hline 198901 & 51.30 & 1 & 7186.9 & 3.09 \\
\hline 198902 & 58.90 & 1 & 7263.3 & 3.03 \\
\hline 198903 & 56.53 & 1 & 7326.3 & 3.21 \\
\hline 198904 & 58.33 & 1 & 7451.7 & 0.88 \\
\hline 199001 & 63.10 & 1 & 7490.2 & 4.24 \\
\hline 199002 & 51.67 & 1 & 7586.4 & 1.60 \\
\hline
\end{tabular}




\begin{tabular}{|c|c|c|c|c|}
\hline 199003 & 70.83 & 1 & 7625.6 & -0.01 \\
\hline 199004 & 98.20 & 0 & 7727.4 & -3.46 \\
\hline 199101 & 68.73 & 0 & 7799.9 & -1.92 \\
\hline 199102 & 57.10 & 0 & 7858.3 & 2.73 \\
\hline 199103 & 60.03 & 0 & 7920.6 & 1.70 \\
\hline 199104 & 61.80 & 0 & 7937.9 & 1.58 \\
\hline 199201 & 51.93 & 0 & 8020.8 & 4.46 \\
\hline 199202 & 59.83 & 0 & 8052.7 & 4.32 \\
\hline 199203 & 61.83 & 0 & 8052.6 & 4.19 \\
\hline 199204 & 58.57 & 0 & 7982 & 4.27 \\
\hline 199301 & 55.40 & 0 & 7943.4 & 0.74 \\
\hline 199302 & 56.17 & 0 & 7997 & 2.58 \\
\hline 199303 & 48.33 & 0 & 8030.7 & 2.12 \\
\hline 199304 & 45.57 & 0 & 8062.2 & 5.39 \\
\hline 199401 & 38.90 & 0 & 8150.7 & 3.95 \\
\hline 199402 & 48.17 & 1 & 8237.3 & 5.59 \\
\hline 199403 & 52.97 & 1 & 8322.3 & 2.60 \\
\hline 199404 & 48.50 & 0 & 8409.8 & 4.52 \\
\hline 199501 & 50.00 & 0 & 8425.3 & 0.99 \\
\hline 199502 & 54.87 & 0 & 8479.2 & 0.86 \\
\hline 199503 & 49.60 & 0 & 8523.8 & 3.40 \\
\hline 199504 & 49.83 & 1 & 8636.4 & 2.82 \\
\hline 199601 & 55.50 & 1 & 8720.5 & 2.77 \\
\hline 199602 & 61.57 & 1 & 8839.8 & 7.10 \\
\hline 199603 & 63.03 & 1 & 8896.7 & 3.53 \\
\hline 199604 & 70.47 & 1 & 8995.5 & 4.44 \\
\hline 199701 & 64.73 & 0 & 9017.6 & 3.11 \\
\hline 199702 & 56.03 & 0 & 9037 & 6.06 \\
\hline 199703 & 54.37 & 0 & 9112.9 & 5.12 \\
\hline 199704 & 54.83 & 0 & 9176.4 & 3.10 \\
\hline 199801 & 40.80 & 0 & 9239.3 & 3.83 \\
\hline 199802 & 36.67 & 0 & 9399 & 3.65 \\
\hline 199803 & 34.10 & 0 & 9480.8 & 5.38 \\
\hline 199804 & 31.33 & 0 & 9584.3 & 7.10 \\
\hline 199901 & 29.90 & 1 & 9658 & 3.61 \\
\hline
\end{tabular}




\begin{tabular}{|c|c|c|c|c|}
\hline 199902 & 46.13 & 1 & 9801.2 & 3.16 \\
\hline 199903 & 58.80 & 1 & 9924.2 & 5.19 \\
\hline 199904 & 66.20 & 1 & 10000.3 & 7.38 \\
\hline 200001 & 80.87 & 1 & 10094.8 & 1.05 \\
\hline 200002 & 79.67 & 1 & 10185.6 & 8.03 \\
\hline 200003 & 90.00 & 1 & 10320 & 0.34 \\
\hline 200004 & 90.23 & 1 & 10498.6 & 2.39 \\
\hline 200101 & 76.40 & 0 & 10592.1 & -1.31 \\
\hline 200102 & 76.40 & 0 & 10674.9 & 2.64 \\
\hline 200103 & 72.80 & 0 & 10810.7 & -1.10 \\
\hline 200104 & 51.20 & 0 & 11004.8 & 1.41 \\
\hline 200201 & 55.70 & 1 & 11033.6 & 3.46 \\
\hline 200202 & 70.47 & 1 & 11248.8 & 2.14 \\
\hline 200203 & 72.87 & 1 & 11258.3 & 2.05 \\
\hline 200204 & 72.40 & 1 & 11325 & 0.14 \\
\hline 200301 & 92.13 & 1 & 11287.8 & 1.68 \\
\hline 200302 & 77.47 & 1 & 11361.7 & 3.43 \\
\hline 200303 & 80.40 & 1 & 11330.4 & 6.75 \\
\hline 200304 & 81.80 & 1 & 11370 & 3.67 \\
\hline 200401 & 92.47 & 1 & 11467.1 & 2.66 \\
\hline 200402 & 101.37 & 1 & 11528.1 & 2.60 \\
\hline 200403 & 114.37 & 1 & 11586.6 & 3.01 \\
\hline 200404 & 124.53 & 1 & 11590.6 & 3.31 \\
\hline 200501 & 129.50 & 1 & 11638.9 & 4.19 \\
\hline 200502 & 140.10 & 1 & 11737.5 & 1.79 \\
\hline 200503 & 168.37 & 1 & 11930.7 & 3.21 \\
\hline 200504 & 162.27 & 1 & 12038.6 & 2.07 \\
\hline 200601 & 166.47 & 1 & 12117.9 & 5.15 \\
\hline 200602 & 188.73 & 1 & 12195.9 & 1.63 \\
\hline 200603 & 190.97 & 1 & 12286.7 & 0.05 \\
\hline 200604 & 157.63 & 0 & 12387.2 & 2.75 \\
\hline 200701 & 153.47 & 0 & 12515 & 0.54 \\
\hline 200702 & 171.70 & 1 & 12570.7 & 3.65 \\
\hline 200703 & 204.27 & 1 & 12670.5 & 2.95 \\
\hline 200704 & 240.90 & 1 & 12735.6 & 1.70 \\
\hline
\end{tabular}




$\begin{array}{llllll}200801 & 269.40 & 1 & 12896.4 & -1.77 & 0 \\ 200802 & 343.80 & 1 & 12948.7 & 1.32 & 0 \\ 200803 & 332.47 & 1 & 12950.4 & -3.66 & 0 \\ 200804 & 157.00 & 0 & 13038.4 & -8.89 & 0 \\ 200901 & 104.47 & 0 & 13056.1 & -5.25 & 0 \\ 200902 & 159.73 & 1 & 13173.6 & -0.31 & 0 \\ 200903 & 179.17 & 1 & 13269.8 & 1.45 & 1 \\ 200904 & 203.50 & 1 & 13326 & 4.03 & 1 \\ 201001 & 215.23 & 1 & 13266.8 & 2.34 & 1 \\ 201002 & 214.90 & 1 & 13310.5 & 2.24 & 1 \\ 201003 & 209.00 & 1 & 13186.9 & 2.60 & 1 \\ 201004 & 235.00 & 1 & 12883.5 & 2.39 & 1 \\ 201101 & 259.03 & 1 & 12711 & 0.08 & 1 \\ 201102 & 292.93 & 1 & 12701 & 2.48 & 1 \\ 201103 & 266.10 & 1 & 12746.7 & 1.28 & 1 \\ 201104 & 283.77 & 0 & 12873.1 & 4.09 & 1 \\ 201201 & 297.47 & 0 & 12947.6 & 1.96 & 1 \\ 201202 & 270.73 & 0 & 13019.6 & 1.25 & 1 \\ 201203 & 267.07 & 1 & 13103.5 & 3.11 & 1 \\ 201204 & 257.97 & 1 & 13181.2 & 0.38 & 1\end{array}$




\section{Appendix B: The Hamilton model}

Table 10: Statistical summary output result for the Hamilton model

\begin{tabular}{|l|r|}
\hline $\begin{array}{l}\text { Regression } \\
\text { Statistics }\end{array}$ & \\
\hline Multiple R & 0.40192833 \\
\hline R Square & 0.16154638 \\
\hline $\begin{array}{l}\text { Adjusted R } \\
\text { Square }\end{array}$ & 0.13063565 \\
\hline $\begin{array}{l}\text { Standard } \\
\text { Error }\end{array}$ & 3.86477517 \\
\hline Observations & 226 \\
\hline
\end{tabular}

ANOVA

\begin{tabular}{|l|r|c|c|c|c|}
\hline & df & SS & MS & $\boldsymbol{F}$ & $\begin{array}{c}\text { Significance } \\
\boldsymbol{F}\end{array}$ \\
\hline Regression & 8 & 624.491324 & 78.0614155 & 5.226223176 & $5.46125 \mathrm{E}-06$ \\
\hline Residual & 217 & 3241.217719 & 14.9364871 & & \\
\hline Total & 225 & 3865.709043 & & & \\
\hline
\end{tabular}

\begin{tabular}{|l|r|r|r|c|}
\hline & \multicolumn{1}{|c|}{ Coefficients } & Standard Error & \multicolumn{1}{c|}{$\boldsymbol{t}$ Stat } & \multicolumn{1}{c|}{$\boldsymbol{P}$-value } \\
\hline Intercept & 2.763348213 & 0.432982613 & 6.382122818 & $1.04242 \mathrm{E}-09$ \\
\hline GDP (t-1) & 0.296374147 & 0.067199419 & 4.410367678 & $1.62424 \mathrm{E}-05$ \\
\hline GDP (t-2) & 0.140377092 & 0.069777979 & 2.011767798 & 0.045480934 \\
\hline GDP (t-3) & -0.09897456 & 0.069660556 & -1.42081208 & 0.156806729 \\
\hline GDP (t-4) & -0.097184286 & 0.06685279 & -1.453705757 & 0.147472608 \\
\hline Oil price (t-1) & -1.232531558 & 2.717961697 & -0.453476427 & 0.650658862 \\
\hline Oil price (t-2) & -4.142147221 & 2.768380833 & -1.496234612 & 0.136045502 \\
\hline Oil price (t-3) & 1.076322451 & 2.762926541 & 0.389558837 & 0.697244842 \\
\hline Oil price (t-4) & -4.446496615 & 2.726438146 & -1.630881163 & 0.104365896 \\
\hline
\end{tabular}




\section{Appendix C: Granger Causality Test}

Granger causality test is a technique to test if one time series variable consistently and predictably changes before another variable.

\section{$\underline{\text { Equation } 1}$}

$\mathbf{G D P}=\mathrm{Bo}+\mathrm{B}_{1} \mathrm{GDP}_{\mathrm{t}-1}+\mathrm{B}_{2} \mathrm{GDP}_{\mathrm{t}-2}+\mathrm{B}_{3} \mathrm{GDP}_{\mathrm{t}-3}+\mathrm{B}_{4} \mathrm{GDP}_{\mathrm{t}-4}+\mathrm{B}_{5} \mathrm{GDP}_{\mathrm{t}-\mathrm{5}}+\mathrm{B}_{6} \mathrm{GDP}_{\mathrm{t}-6}+$ $\mathrm{B}_{7} \mathrm{GDP}_{\mathrm{t}-7}+\mathrm{B}_{8} \mathrm{GDP}_{\mathrm{t}-8}-\alpha_{1} \mathrm{Oilt}-1-\alpha_{2} \mathrm{Oilt}-2-\alpha_{3} \mathrm{Oilt}-3-\alpha_{4} \mathrm{Oilt}-4-\alpha_{5} \mathrm{Oilt}-5-\alpha_{6} \mathrm{Oilt}-6$ $-\alpha_{7} \mathrm{Oili}_{\mathrm{t}-7}-\alpha_{8} \mathrm{Oil} \mathrm{t}_{\mathrm{t}-8}+\mathcal{E}_{\mathrm{t}}$

Table 11: Statistical summary output on equation 1

\begin{tabular}{|l|r|}
\hline \multicolumn{1}{|c|}{$\begin{array}{c}\text { Regression } \\
\text { Statistics }\end{array}$} & \\
\hline Multiple R & 0.459583861 \\
\hline R Square & 0.211217325 \\
\hline $\begin{array}{l}\text { Adjusted R } \\
\text { Square }\end{array}$ & 0.157966174 \\
\hline Standard Error & 3.719900935 \\
\hline Observations & 254 \\
\hline
\end{tabular}

\begin{tabular}{|l|r|c|c|c|c|}
\hline & df & SS & MS & F & $\begin{array}{c}\text { Significance } \\
\text { F }\end{array}$ \\
\hline Regression & 16 & 878.1794501 & 54.88622 & 3.966437 & $1.20028 \mathrm{E}-06$ \\
\hline Residual & 237 & $\mathbf{3 2 7 9 . 5 2 6 1 2 3}$ & 13.83766 & & \\
\hline Total & 253 & 4157.705573 & & & \\
\hline
\end{tabular}

\begin{tabular}{|l|r|r|r|r|}
\hline & \multicolumn{1}{|c|}{ Coefficients } & \multicolumn{1}{c|}{ Standard Error } & \multicolumn{1}{c|}{ t Stat } & \multicolumn{1}{c|}{ P-value } \\
\hline Intercept & 2.472364711 & 0.500867705 & 4.936163 & $1.5 \mathrm{E}-06$ \\
\hline GDP (t-1) & 0.315637794 & 0.064469263 & 4.895942 & $1.81 \mathrm{E}-06$ \\
\hline GDP (t-2) & 0.139522865 & 0.066636676 & 2.093785 & 0.037342 \\
\hline GDP (t-3) & -0.079954202 & 0.067468621 & -1.18506 & 0.237182 \\
\hline GDP (t-4) & -0.047430455 & 0.067416007 & -0.70355 & 0.482404 \\
\hline GDP (t-5) & -0.072758827 & 0.067021442 & -1.08561 & 0.278757 \\
\hline GDP (t-6) & 0.032381099 & 0.066954614 & 0.483628 & 0.629097 \\
\hline
\end{tabular}




\begin{tabular}{|l|r|r|r|r|} 
GDP (t-7) & -0.006648086 & 0.066364735 & -0.10017 & 0.92029 \\
\hline GDP (t-8) & 0.0139683 & 0.062918501 & 0.222006 & 0.8245 \\
\hline Oil price (t-1) & -2.298725295 & 2.090315369 & -1.0997 & 0.272577 \\
\hline Oil price (t-2) & -3.149371601 & 2.147764207 & -1.46635 & 0.143879 \\
\hline Oil price (t-3) & -1.477504809 & 2.183697189 & -0.67661 & 0.499315 \\
\hline Oil price (t-4) & -3.256705611 & 2.170778463 & -1.50025 & 0.134881 \\
\hline Oil price (t-5) & 0.20090958 & 2.180158733 & 0.092154 & 0.926654 \\
\hline Oil price (t-6) & 0.194952372 & 2.188532797 & 0.089079 & 0.929094 \\
\hline Oil price (t-7) & -4.966199813 & 2.152093443 & -2.30761 & 0.021883 \\
\hline Oil price (t-8) & 4.182670212 & 2.118887146 & 1.973994 & 0.049544 \\
\hline
\end{tabular}

\section{$\underline{\text { Equation } 2}$}

$$
\begin{aligned}
\mathbf{G D P}= & \mathrm{Bo}+\mathrm{B}_{1} \mathrm{GDP}_{\mathrm{t}-1}+\mathrm{B}_{2} \mathrm{GDP}_{\mathrm{t}-2}+\mathrm{B}_{3} \mathrm{GDP}_{\mathrm{t}-3}+\mathrm{B}_{4} \mathrm{GDP}_{\mathrm{t}-4}+\mathrm{B}_{5} \mathrm{GDP}_{\mathrm{t}-5}+\mathrm{B}_{6} \mathrm{GDP}_{\mathrm{t}-6} \\
& +\mathrm{B}_{7} \mathrm{GDP}_{\mathrm{t}-7}+\mathrm{B}_{8} \mathrm{GDP}_{\mathrm{t}-\mathrm{8}}+\mathcal{E}_{\mathrm{t}}
\end{aligned}
$$

Table 12: Statistical summary output on equation 2

\begin{tabular}{|l|r|}
\hline $\begin{array}{c}\text { Regression } \\
\text { Statistics }\end{array}$ & \\
\hline Multiple R & 0.398916681 \\
\hline R Square & 0.159134518 \\
\hline $\begin{array}{l}\text { Adjusted R } \\
\text { Square }\end{array}$ & 0.131677686 \\
\hline $\begin{array}{l}\text { Standard } \\
\text { Error }\end{array}$ & 3.777522728 \\
\hline Observations & 254 \\
\hline
\end{tabular}

\begin{tabular}{|l|r|r|c|c|c|}
\hline & df & \multicolumn{1}{|c|}{ SS } & MS & F & $\begin{array}{c}\text { Significance } \\
\text { F }\end{array}$ \\
\hline Regression & 8 & 661.634473 & 82.70430912 & 5.795807681 & $8.880 \mathrm{E}-07$ \\
\hline Residual & 245 & $\mathbf{3 4 9 6 . 0 7 1 1}$ & 14.26967796 & & \\
\hline Total & 253 & 4157.705573 & & & \\
\hline
\end{tabular}

\begin{tabular}{|l|l|r|c|c|}
\hline & Coefficients & Standard Error & \multicolumn{1}{c|}{ Stat } & $\boldsymbol{P}$-value \\
\hline Intercept & 2.335036666 & 0.474820513 & 4.917724917 & $1.60582 \mathrm{E}-06$ \\
\hline GDP (t-1) & 0.322496097 & 0.063957685 & 5.042335351 & $8.95018 \mathrm{E}-07$ \\
\hline
\end{tabular}




\begin{tabular}{|l|r|r|r|r|} 
GDP (t-2) & 0.140974751 & 0.066854029 & 2.108694927 & 0.035986296 \\
\hline GDP (t-3) & -0.059645313 & 0.067429716 & -0.884555297 & 0.377263776 \\
\hline GDP (t-4) & -0.056169425 & 0.067313788 & -0.834441597 & 0.404845065 \\
\hline GDP (t-5) & -0.081234916 & 0.067251458 & -1.207927953 & 0.228239678 \\
\hline GDP (t-6) & 0.034028601 & 0.067295522 & 0.505659211 & 0.613550534 \\
\hline GDP (t-7) & -0.010173559 & 0.06673089 & -0.152456511 & 0.878952366 \\
\hline GDP (t-8) & $-2.18942 E-05$ & 0.063193693 & -0.000346462 & 0.999723846 \\
\hline
\end{tabular}

\section{$\underline{\text { Equation } 3}$}

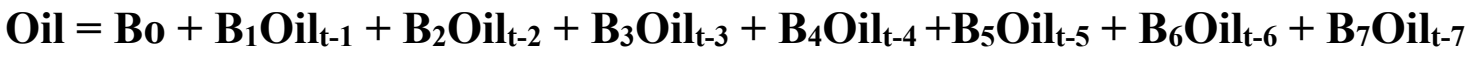

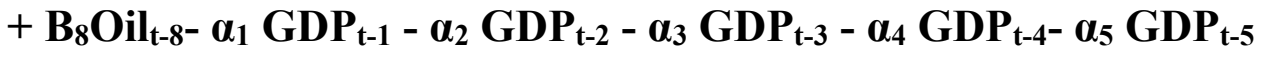

$$
\begin{aligned}
& -\alpha_{6} \operatorname{GDP}_{\mathrm{t}-6}-\alpha_{7} \mathrm{GDP}_{\mathrm{t}-7}-\alpha_{8} \mathrm{GDP}_{\mathrm{t}-8}+\mathcal{E}_{\mathrm{t}}
\end{aligned}
$$

Table 13: Statistical summary output on equation 3

\begin{tabular}{|l|r|}
\hline \multicolumn{1}{|c|}{$\begin{array}{c}\text { Regression } \\
\text { Statistics }\end{array}$} & \\
\hline Multiple R & 0.33156925 \\
\hline R Square & 0.109938168 \\
\hline $\begin{array}{l}\text { Adjusted R } \\
\text { Square }\end{array}$ & 0.049849605 \\
\hline Standard Error & 0.115703818 \\
\hline Observations & 254 \\
\hline
\end{tabular}

\begin{tabular}{|l|r|c|c|c|c|}
\hline & df & SS & MS & F & $\begin{array}{c}\text { Significance } \\
\text { F }\end{array}$ \\
\hline Regression & 16 & 0.39189709 & 0.024494 & 1.829602 & 0.028275945 \\
\hline Residual & 237 & $\mathbf{3 . 1 7 2 8 0 7 4 9 5}$ & 0.013387 & & \\
\hline Total & 253 & 3.564704585 & & & \\
\hline
\end{tabular}

\begin{tabular}{|l|c|r|r|l|}
\hline & \multicolumn{1}{|c|}{ Coefficients } & \multicolumn{1}{c|}{ Standard Error } & \multicolumn{1}{c|}{ t Stat } & P-value \\
\hline Intercept & 0.009052397 & 0.015578992 & 0.581064 & 0.561749 \\
\hline Oil price (t-1) & 0.238404894 & 0.06501718 & 3.666798 & 0.000303 \\
\hline
\end{tabular}




\begin{tabular}{|l|r|r|r|r|} 
Oil price (t-2) & -0.167971076 & 0.066804069 & -2.51438 & 0.012588 \\
\hline Oil price (t-3) & 0.060898924 & 0.067921728 & 0.896604 & 0.37084 \\
\hline Oil price (t-4) & -0.092711728 & 0.067519904 & -1.3731 & 0.171018 \\
\hline Oil price (t-5) & -0.112673029 & 0.067811668 & -1.66156 & 0.097924 \\
\hline Oil price (t-6) & 0.038141997 & 0.068072135 & 0.560317 & 0.575792 \\
\hline Oil price (t-7) & 0.025461711 & 0.066938725 & 0.380373 & 0.704009 \\
\hline Oil price (t-8) & -0.019030187 & 0.065905877 & -0.28875 & 0.773027 \\
\hline GDP (t-1) & 0.001591673 & 0.002005252 & 0.793752 & 0.428134 \\
\hline GDP (t-2) & -0.002659799 & 0.002072668 & -1.28327 & 0.20065 \\
\hline GDP (t-3) & 0.00018026 & 0.002098544 & 0.085898 & 0.93162 \\
\hline GDP (t-4) & 0.001606013 & 0.002096908 & 0.765896 & 0.4445 \\
\hline GDP (t-5) & 0.000964366 & 0.002084635 & 0.462607 & 0.644071 \\
\hline GDP (t-6) & -0.001773354 & 0.002082557 & -0.85153 & 0.395336 \\
\hline GDP (t-7) & 0.002330982 & 0.002064209 & 1.129237 & 0.259939 \\
\hline GDP (t-8) & -0.000668776 & 0.001957017 & -0.34173 & 0.732855 \\
\hline
\end{tabular}

\section{$\underline{\text { Equation } 4}$}

$$
\begin{aligned}
\text { Oil }= & \text { Bo }+ \text { B }_{1} \mathrm{Oil}_{t-1}+\mathbf{B}_{2} \mathrm{Oil}_{\mathrm{t}-2}+\mathrm{B}_{3} \mathrm{Oil}_{\mathrm{t}-3}+\mathrm{B}_{4} \mathrm{Oil}_{\mathrm{t}-4}+\mathrm{B}_{5} \mathrm{Oil}_{\mathrm{t}-5}+\mathrm{B}_{6} \mathrm{Oil}_{\mathrm{t}-6}+\mathrm{B}_{7} \mathrm{Oil}_{\mathrm{t}-7} \\
& +\mathrm{B}_{8} \mathrm{Oil}_{\mathrm{t}-\mathrm{8}}+\mathcal{E}_{\mathrm{t}}
\end{aligned}
$$

Table 14: Statistical summary output on equation 4

\begin{tabular}{|l|r|}
\hline $\begin{array}{l}\text { Regression } \\
\text { Statistics }\end{array}$ & \\
\hline Multiple R & 0.305666057 \\
\hline R Square & 0.093431738 \\
\hline $\begin{array}{l}\text { Adjusted R } \\
\text { Square }\end{array}$ & 0.063829509 \\
\hline $\begin{array}{l}\text { Standard } \\
\text { Error }\end{array}$ & 0.114849467 \\
\hline Observations & 254 \\
\hline
\end{tabular}

\begin{tabular}{|l|r|r|r|c|c|}
\hline & df & \multicolumn{1}{|c|}{ SS } & MS & $\boldsymbol{F}$ & $\begin{array}{c}\text { Significance } \\
\boldsymbol{F}\end{array}$ \\
\hline Regression & 8 & 0.333056545 & 0.041632068 & 3.156239966 & 0.002022927 \\
\hline Residual & 245 & $\mathbf{3 . 2 3 1 6 4 8 0 4}$ & 0.0131904 & & \\
\hline Total & 253 & 3.564704585 & & & \\
\hline
\end{tabular}




\begin{tabular}{|l|r|r|r|c|}
\hline & \multicolumn{1}{|c|}{ Coefficients } & \multicolumn{1}{c|}{ Standard Error } & \multicolumn{1}{c|}{ Stat } & \multicolumn{1}{c|}{-value } \\
\hline Intercept & 0.01453078 & 0.007639411 & 1.902081048 & 0.058333374 \\
\hline Oil price (t-1) & 0.231597986 & 0.063954908 & 3.621269955 & 0.000356246 \\
\hline Oil price (t-2) & -0.170707179 & 0.065637937 & -2.600739566 & 0.009867888 \\
\hline Oil price (t-3) & 0.06101506 & 0.066564132 & 0.916635713 & 0.360234953 \\
\hline Oil price (t-4) & -0.084897634 & 0.066208474 & -1.28227747 & 0.200957279 \\
\hline Oil price (t-5) & -0.125918637 & 0.066197998 & -1.902151741 & 0.058324089 \\
\hline Oil price (t-6) & 0.050561135 & 0.06632007 & 0.762380601 & 0.446566226 \\
\hline Oil price (t-7) & 0.017863095 & 0.065613871 & 0.272245713 & 0.785662391 \\
\hline Oil price (t-8) & -0.02947327 & 0.063885039 & -0.461348545 & 0.644957882 \\
\hline
\end{tabular}




\section{Appendix D: F-statistics calculation}

$\mathrm{F}_{\mathrm{c}}=\frac{\left(\mathrm{SSR}_{\mathrm{r}}-\mathrm{SSR}_{\mathrm{ur}}\right) / \mathrm{M}}{\mathrm{SSR}_{\mathrm{ur}} /(\mathrm{N}-\mathrm{K}-1)}$

Where $\mathrm{SSR}_{\mathrm{r}}=$ residual sum of squares from the constrained equation

$\mathrm{SSR}_{\mathrm{ur}}=$ residual sum of squares from the unconstrained equation

$\mathrm{M}=$ the number of constrained (or the number of coefficients being jointly tested)

$\mathrm{N}=$ the number of observation

$\mathrm{K}=$ the number of independence variables in the unconstrained equation.

The F-statistics was found using the Granger Causality test for oil prices cause of recessions. For the unconstrained equation, equation 1 is used from appendix $\mathrm{C}$ to find $\mathrm{SSR}_{\mathrm{ur}}$ which calculate to be 3279.52. The constrained equation, equation 2 is used from appendix $\mathrm{C}$ to find $\mathrm{SSR}_{\mathrm{r}}$ which calculate to be 3496.07 . M is equal to eight because in equation 2 have the eight lagged of change values for the quarterly GDP growth rate. $\mathrm{K}$ is equal 16 because in equation 1, there are eight lagged of change values for the quarterly GDP growth rate and the eight lagged of change value for the logarithmic change in oil price.

$$
\begin{aligned}
\mathrm{F}_{\mathrm{c}} & =\frac{(3496.07-3279.53) / 8}{3279.53 /(254-16-1)} \\
& =1.95
\end{aligned}
$$

The F-statistics was found using the Granger Causality test for recessions cause of oil prices. For the unconstrained equation, equation 3 is used from appendix $\mathrm{C}$ to find $\mathrm{SSR}_{\mathrm{ur}}$ which calculate to be 3.17. The constrained equation, equation 4 is used from appendix $\mathrm{C}$ to find $\mathrm{SSR}_{\mathrm{r}}$ which calculate to be 3.23. $\mathrm{M}$ is 
equal to eight because in equation 4 have the eight lagged of change value for the logarithmic change in oil price. $\mathrm{K}$ is equal 16 because in equation 3 , there are eight lagged of change values for the quarterly GDP growth rate and the eight lagged of change value for the logarithmic change in oil price.

$$
\begin{aligned}
F_{c} & =\frac{(3.23-3.17) / 8}{3.17 /(254} \\
& =0.054
\end{aligned}
$$




\section{Appendix E: Overview of the studies cited and their principal results}

Table 15: Overview of the studies cited and their principal results

\begin{tabular}{|c|c|c|}
\hline Authors and period studied & Objective / General idea & Results \\
\hline Hamilton (1983) 1948-1980 & $\begin{array}{l}\text { Illustrate that the } \\
\text { correlation between oil } \\
\text { shock and the US } \\
\text { recessions is not statics } \\
\text { coincidence }\end{array}$ & $\begin{array}{l}\text { The result of increases in } \\
\text { oil price caused a decline } \\
\text { of output within } 3-4 \\
\text { quarters later. Also, it will } \\
\text { take } 1 \text { to } 2 \text { years for the } \\
\text { economy to begin to } \\
\text { recover the output } \\
\text { growth. }\end{array}$ \\
\hline $\begin{array}{l}\text { Gisser, Goodwin (1986) } \\
\text { 1961-1982 }\end{array}$ & $\begin{array}{l}\text { Replicate Hamilton's } \\
\text { results in 1983, compare } \\
\text { with relationship between } \\
\text { oil prices and output before } \\
\text { or after } 1973 .\end{array}$ & $\begin{array}{l}\text { Monetary and fiscal } \\
\text { policy cannot only just } \\
\text { explain the result of } \\
\text { increased oil price due to } \\
\text { economic output. } \\
\text { The effect on the oil } \\
\text { prices that affects the } \\
\text { economy have not } \\
\text { changed since } 1973 \text {. }\end{array}$ \\
\hline $\begin{array}{l}\text { Loungani (1986) 1947-1982 } \\
\text { Quarterly employment data for } \\
28 \text { industries }\end{array}$ & $\begin{array}{l}\text { Purposed that all the } \\
\text { interruptions that occurred } \\
\text { in the global oil market } \\
\text { caused unemployment } \\
\text { through sector rotation. }\end{array}$ & $\begin{array}{l}\text { Labor reallocation } \\
\text { process is the main } \\
\text { reason for the increase in } \\
\text { oil prices in 1950s and } \\
1970 \text { s. }\end{array}$ \\
\hline Mork (1989) 1948-1988 & $\begin{array}{l}\text { Replicate Hamilton's result } \\
\text { in } 1983 \text { of a negative } \\
\text { correlation between } \\
\text { increases in oil prices and } \\
\text { the output growth and } \\
\text { adjust the data unit } 1988 .\end{array}$ & $\begin{array}{l}\text { Analyses of Hamilton's } \\
\text { result are still correct } \\
\text { when the oil market } \\
\text { collapse of the } 1980 \text { s. Oil } \\
\text { prices are still considered } \\
\text { part of reason why the } \\
\text { market collapses. }\end{array}$ \\
\hline
\end{tabular}




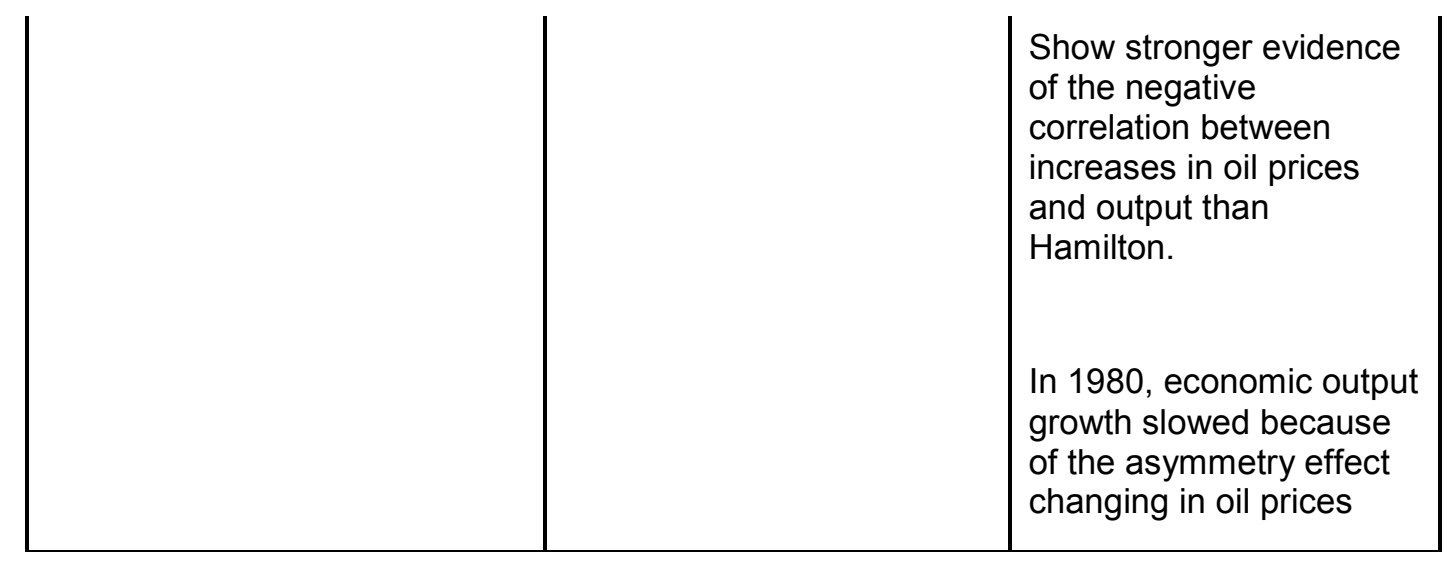

\begin{tabular}{|c|c|c|}
\hline Authors and period studied & Objective / General idea & Results \\
\hline Lee et al. (1995) 1950-1992 & $\begin{array}{l}\text { The important point of how } \\
\text { to measure the oil price } \\
\text { shock by a change in the } \\
\text { given oil price differs from } \\
\text { the historical pattern }\end{array}$ & $\begin{array}{l}\text { Oil shocks have a great } \\
\text { impact on the volatile } \\
\text { environment. } \\
\text { For growth rate output- } \\
\text { The negative affect from } \\
\text { oil price shock happened } \\
4 \text { quarters later, recovery } \\
\text { after } 6 \text { quarters after the } \\
\text { shock } \\
\text { For Unemployment } \\
\text { happened } 4-8 \text { quarters } \\
\text { after the oil }\end{array}$ \\
\hline $\begin{array}{l}\text { Ferderer (1996) 1970-1990 } \\
\text { daily spot market oil prices }\end{array}$ & 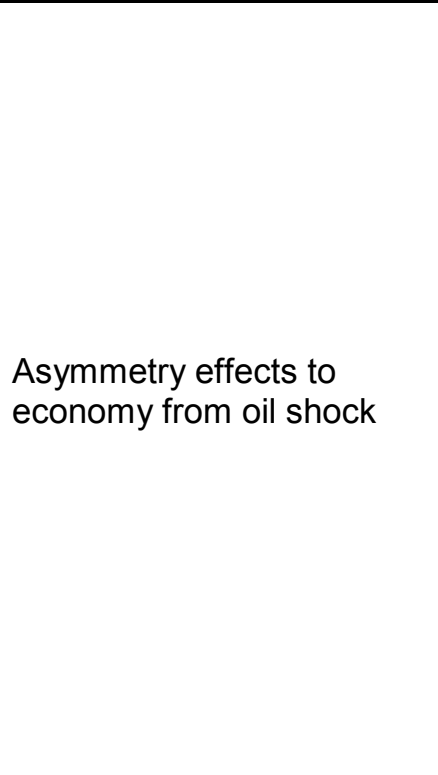 & $\begin{array}{l}\text { Monetary policy has } \\
\text { less impact on economic } \\
\text { activity that volatility and } \\
\text { oil price changes } \\
\text { Oil price increases } \\
\text { causing to have high } \\
\text { volatility } \\
\text { The industrial } \\
\text { production use oil price } \\
\text { volatility and the Federal } \\
\text { funds rate to explain } \\
\text { fluctuations that occur. } \\
\text { Negative volatility has } \\
\text { a significant impact on } \\
\text { output growth, gain in } \\
\text { output will happened } 11 \\
\text { months later }\end{array}$ \\
\hline
\end{tabular}




\begin{tabular}{|c|c|c|}
\hline & & $\begin{array}{l}\quad \text { Output growth has a } \\
\text { significant impact after oil } \\
\text { price changes about } 12 \\
\text { months }\end{array}$ \\
\hline $\begin{array}{l}\text { Rotemberg and Woodford } \\
\text { (1996) 1948-1980 }\end{array}$ & & $\begin{array}{l}\text { Output growth and real } \\
\text { wages can explain the } \\
\text { great effect of oil price } \\
\text { change in the imperfectly } \\
\text { competitive market. } \\
\text { A } 1 \% \text { increase in oil } \\
\text { prices results in a } \\
\text { reduction in output of } \\
\text { about }-.25 \text { percent after } 5 \\
-7 \text { quarters } \\
\text { After } 5 \text { or } 6 \text { quarters } \\
\text { after the oil price increase } \\
\text { by } 10 \% \text {, real wages fall by } \\
1 \% \\
\text { Second year after the } \\
\text { oil price shock, it is more } \\
\text { important in decline, in } \\
\text { output, and real wages } \\
\text { gains. }\end{array}$ \\
\hline Hooker (1996) 1948-1994 & $\begin{array}{l}\text { Proved the linear relation } \\
\text { (Hamiltion 1983) and the } \\
\text { asymmetric relation (Mork } \\
\text { 1989) between oil prices } \\
\text { and output }\end{array}$ & $\begin{array}{l}1948-1972: \\
10 \% \text { increase in oil prices } \\
\text { caused the GDP growth } \\
\text { rate to decrease by } 0.6 \% \\
\text { in the 3rd-4th quarters } \\
\text { later } \\
\text { 1973-1994: } \\
\text { Oil prices can be used to } \\
\text { predict unemployment } \\
\text { and GDP growth. } \\
\text { However, volatility can } \\
\text { sometimes be used for } \\
\text { predict of GDP growth }\end{array}$ \\
\hline Hamilton (1996) 1973-1994 & $\begin{array}{l}\text { Due to the oil price } \\
\text { volatility since 1986, he } \\
\text { tried to analyze oil price } \\
\text { development (net oil price } \\
\text { increase (NOPI)) }\end{array}$ & $\begin{array}{l}\text { During period from } 1948 \\
\text { to } 1994, \text { relation between } \\
\text { GDP growth and NOPI } \\
\text { remains statistically } \\
\text { significant }\end{array}$ \\
\hline Hamilton (2000) 1949:1999 & & $\begin{array}{l}\text { Oil price increases have a } \\
\text { larger effect than oil price } \\
\text { decreases. A long period } \\
\text { of stable prices has a } \\
\text { bigger impact than simply } \\
\text { correcting previous } \\
\text { decreases. }\end{array}$ \\
\hline
\end{tabular}




\begin{tabular}{|l|l|l|} 
& $\begin{array}{l}\text { From 1949 to 1980 a 10\% } \\
\text { increase in oil prices } \\
\text { resulted, 4 quarters later, } \\
\text { in GDP growth rate } \\
\text { having dropped 1.4\%. }\end{array}$ \\
\hline Chaudhuri (2000) 1973-1996 & $\begin{array}{l}\text { Real oil prices have an } \\
\text { influence on real } \\
\text { commodity and may } \\
\text { affect the primary } \\
\text { commodity prices, even if } \\
\text { oil is not being used } \\
\text { directly in the production } \\
\text { of those commodities. }\end{array}$ \\
\hline
\end{tabular}

